\title{
كفايات القياس والتقويم لاى معلمة التعليم العام بتبوك وفق المعايير العالمية في ضوء بعض المتغيرات
}

\author{
أحمد سليم المسعودي \\ أستاذ مشارك في التعلم والفروق الفردية- جامعة تبوك- المملكة العربية السعودية \\ Unm3030@yahoo.com \\ هند عبدالله الجـاسر \\ ماجستير في القياس التقويم-وزارة التربية والتعليم \\ h-m-r44@hotmail.com
}

يهدف البحث إلى تحديد كفايات القياس والتقويم لدى معلمة التعليم العام بتبوك وفق المعايير العالمية في ضوء بعض المتغيرات. وقد تم بناء

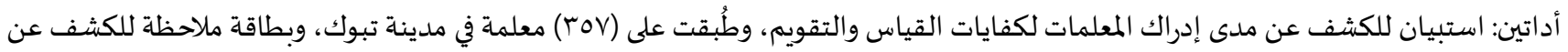

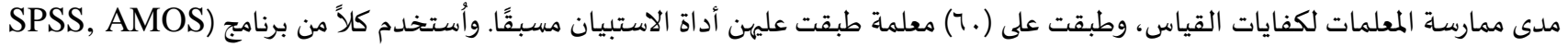

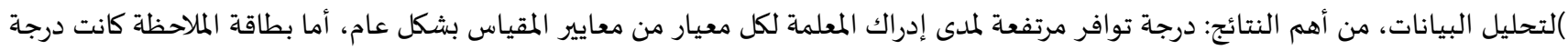

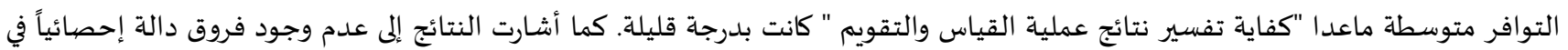

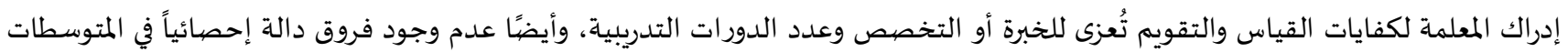

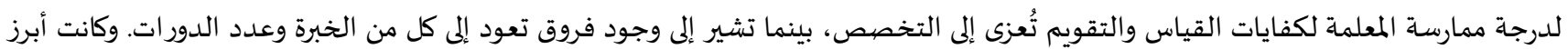
التوصيات الاستفادة من قائمة المهارات الواردة في هذ البحث كإطار مرجعي يساعد المعلمة في التقويم الذاتي لكفاءتها في القياس والتقويم.

الكلمات المفتاحية: كفايات القياس والتقويم، المعايير العالميية.

\section{() (1)}

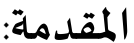

يحتل القياس مكانة مهمة في العلوم المختلفة، وفي مجالات الحياة الإنسانية المعاصرة. ولعل بين السمات المهمة لحضارتنا المعاصرة اعتمادها

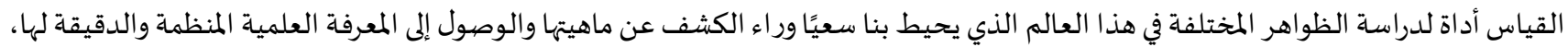

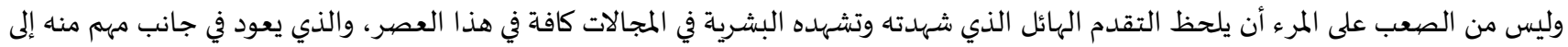

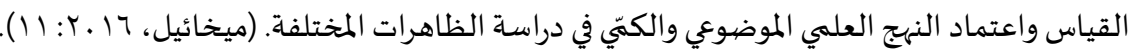

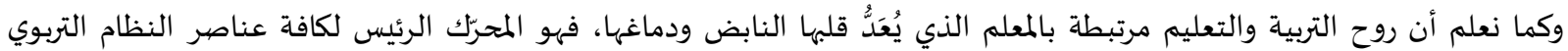

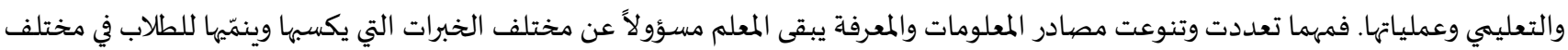

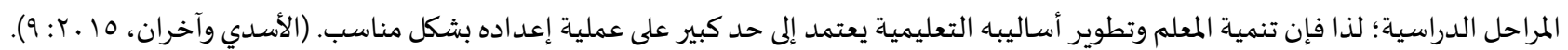

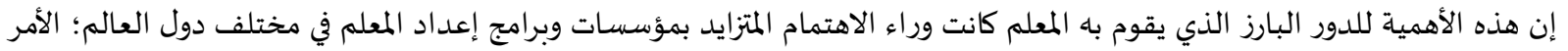

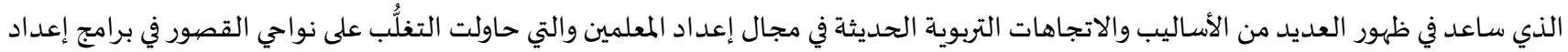

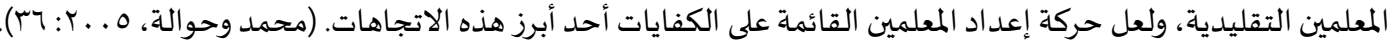

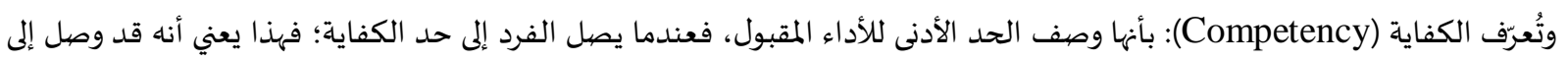

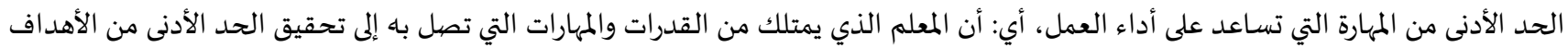

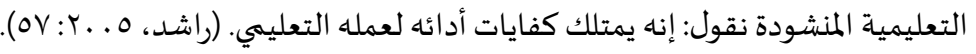


وبما أن الكفايات مشكلة شغلت فكر الباحثين والتربويين الأوائل، وأثار فيهم تساؤلات مشروعة تابعتها باهتمام وجدية الجامعاتُ وكليات التربية التراية

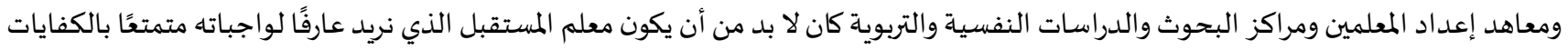
التعليمية اللازمة لعمله، وفق أسس تربوية حديثة تواكب التطور المستمر في التماثل التعليم، بحيث ينعكس أثر هذه المعرفة على مستويات تحصيل الطلبة.

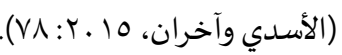

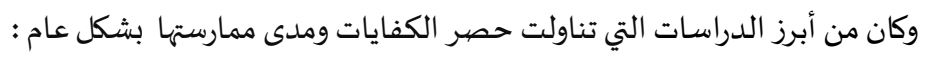

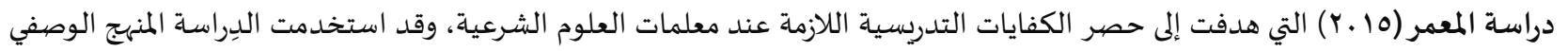

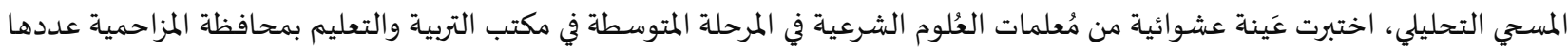

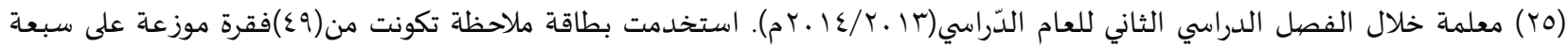

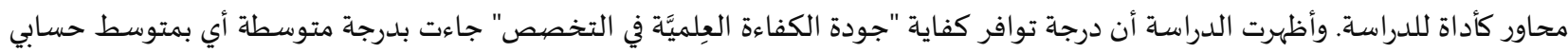

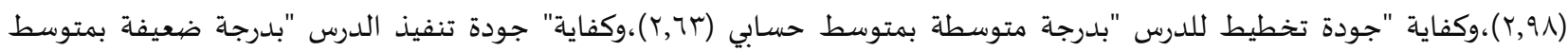

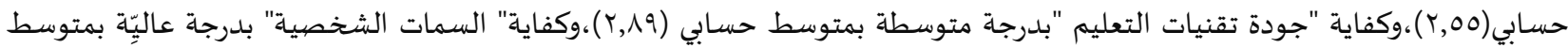

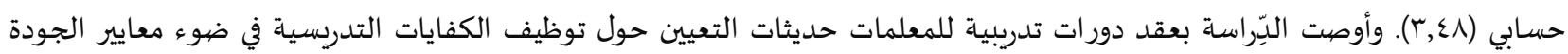

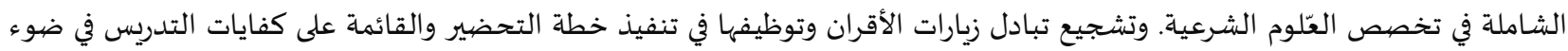

معايير الجودة الشامِلة.

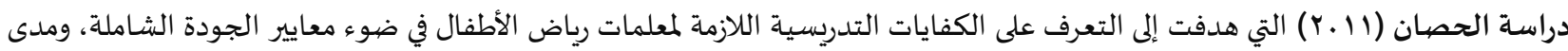

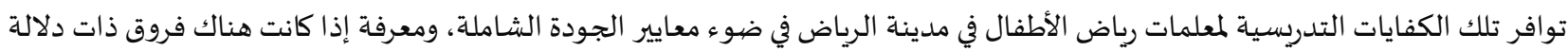

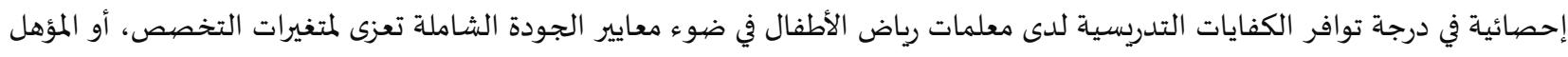

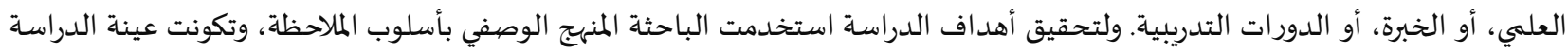

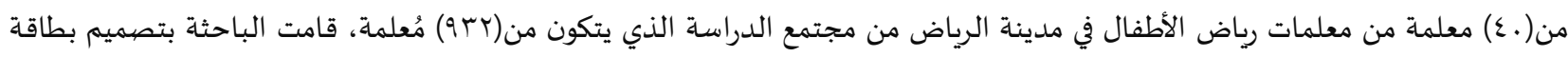

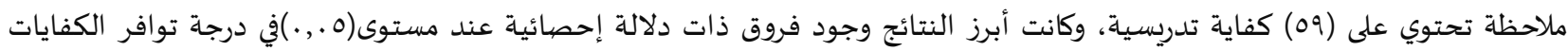

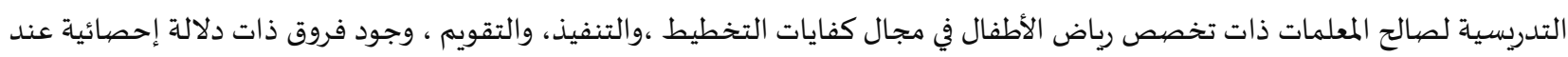

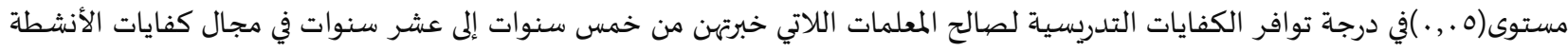
والوسائل التعليمية.

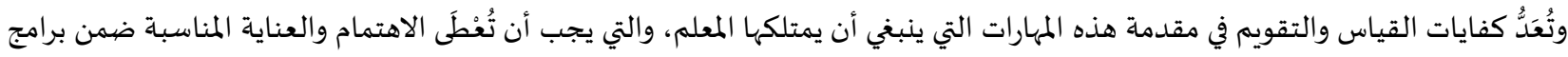

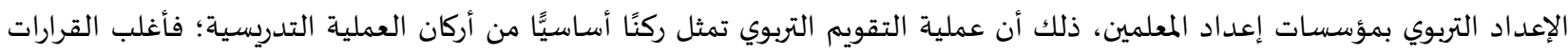

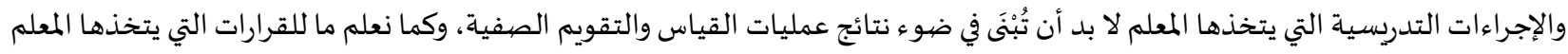

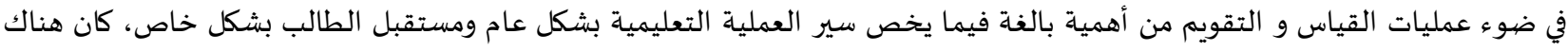

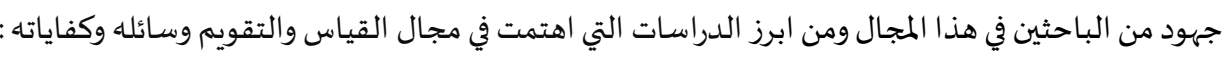

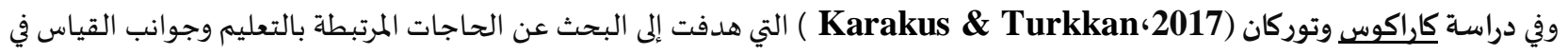

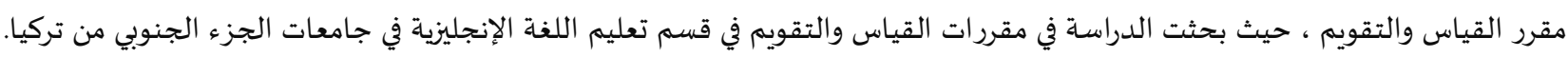

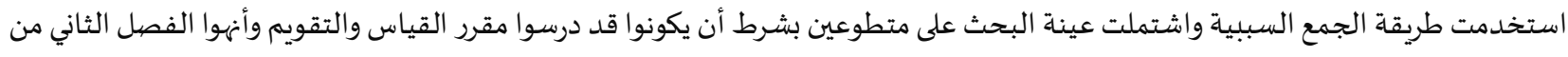

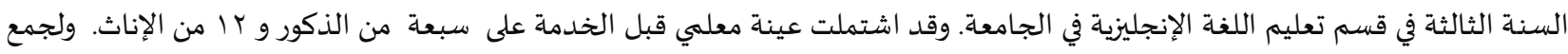

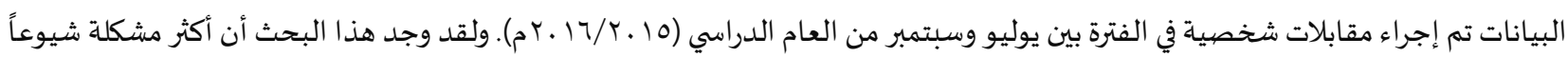

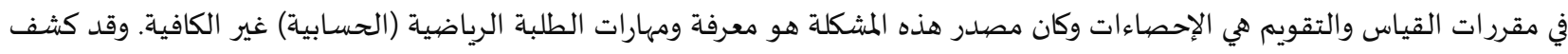

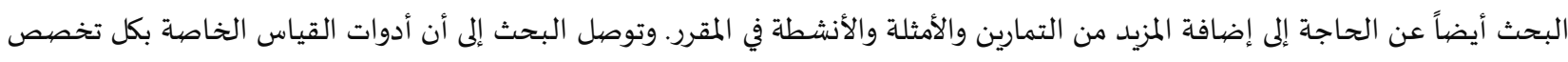

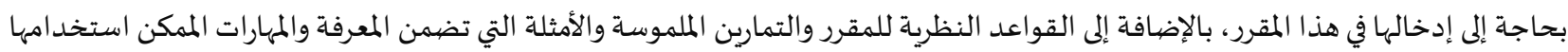
في مهنة التعليم والتي يمكن إضافتها للمقررات العلمياة.

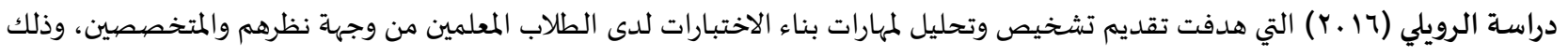

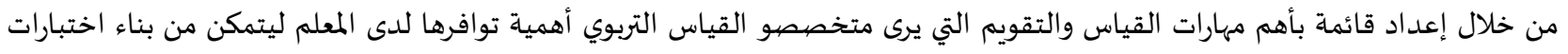

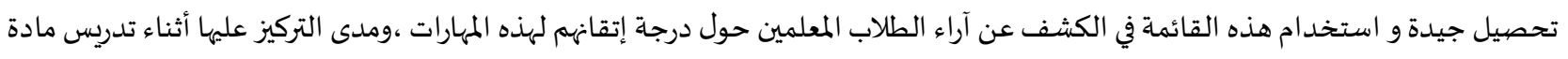

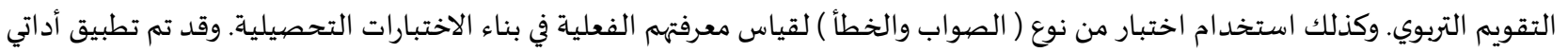


الدراسة على عينة مكونة من (.2V ) طالباً تم اختيارهم عشوائياً بطريقة العينة متعددة المراحل من مجتمع طلاب كليات المعلمين الذين درسوا

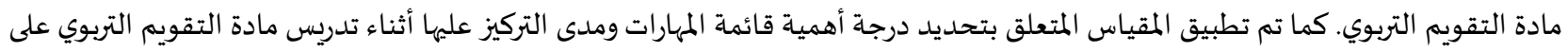

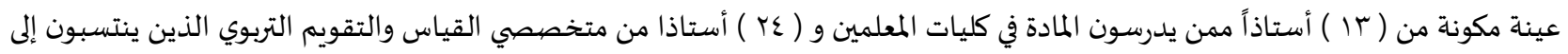

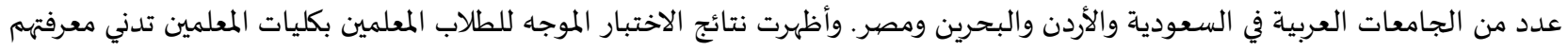

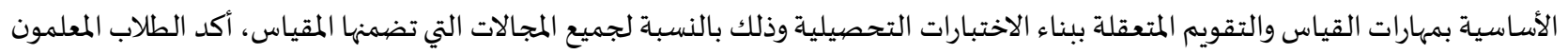

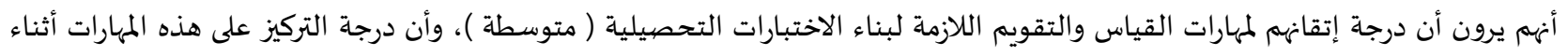

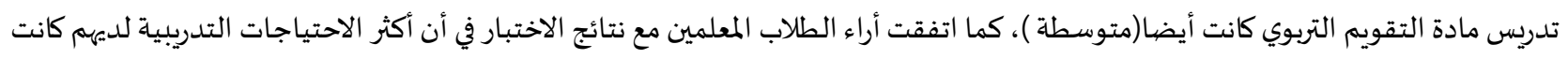

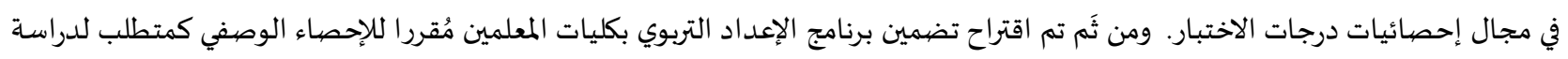

دراسة كلوي (Koloi 2016) بعنوان التدربب على التقييم: شرط مسبق لكفاءات المدرسين ومهاراتهم في استخدام التقييم الصفي ، تم توزيع

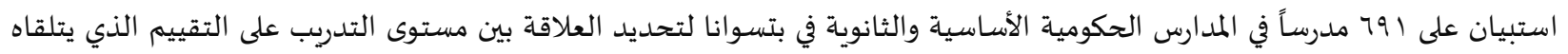

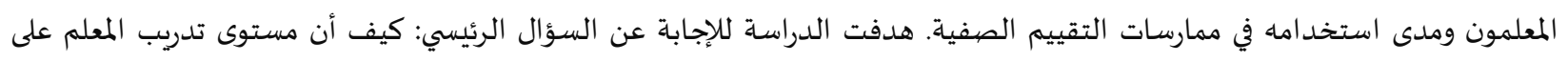

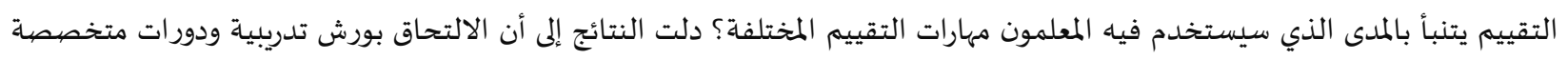

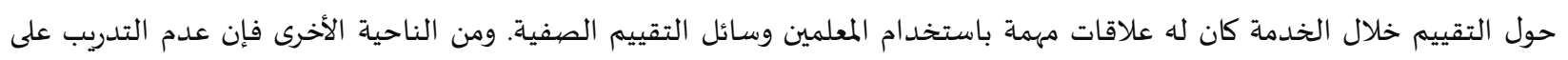

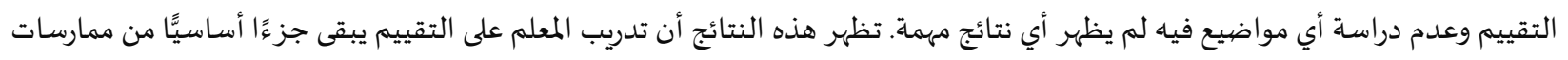

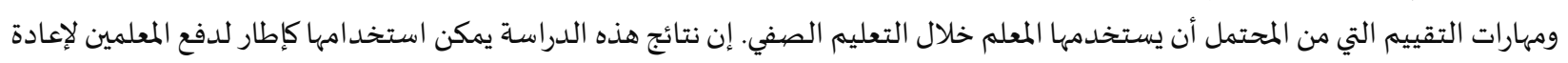

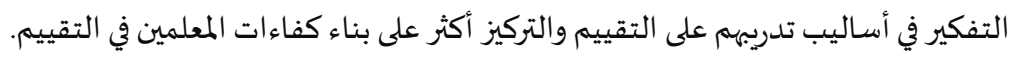

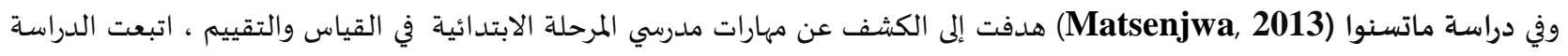

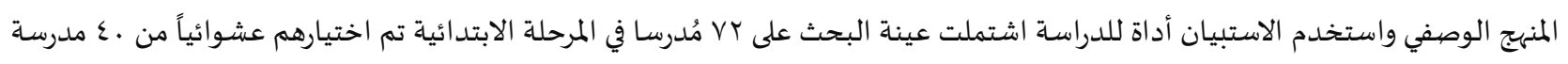

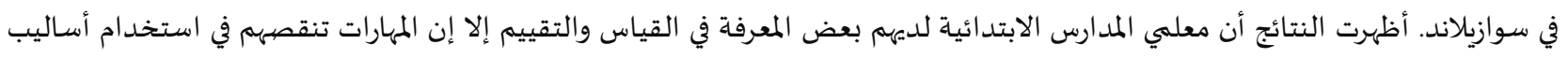

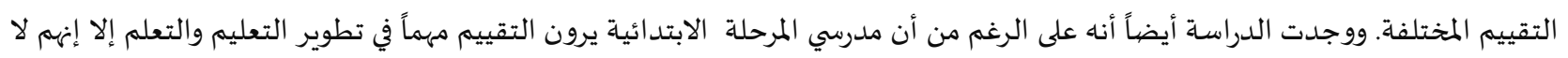

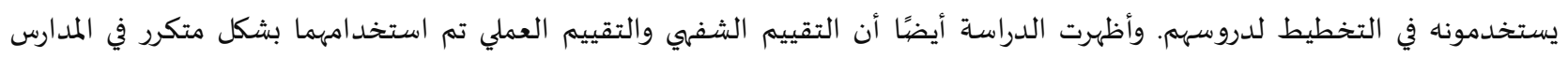

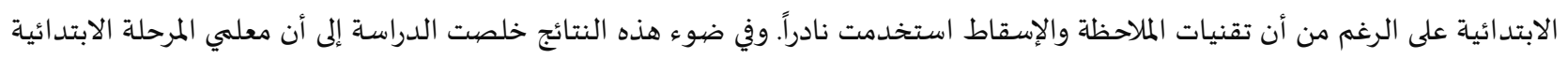

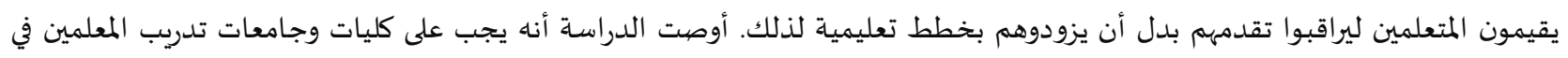

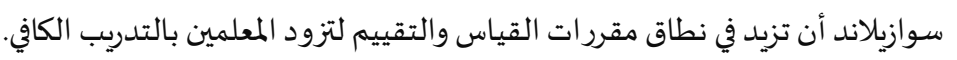

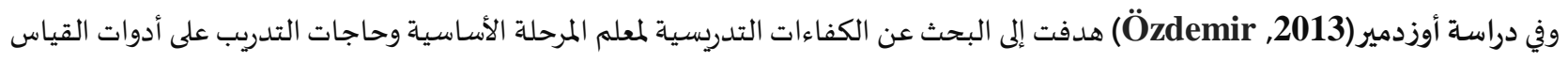

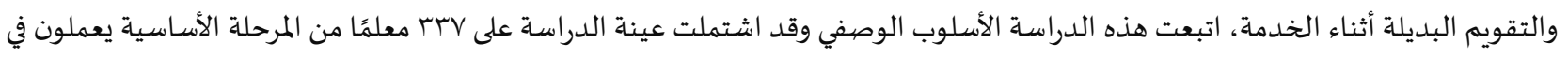

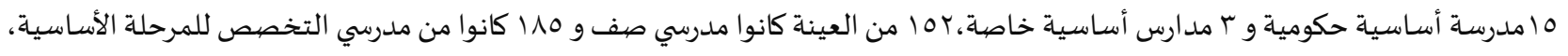

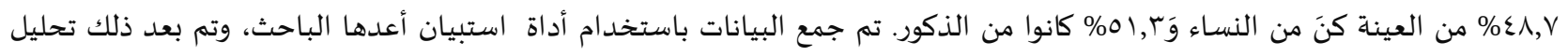

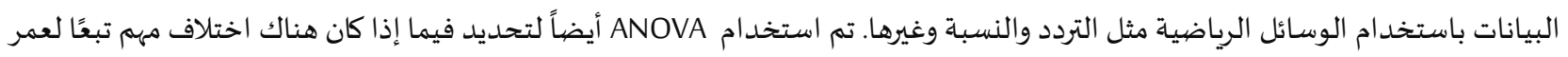

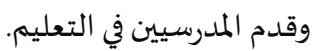

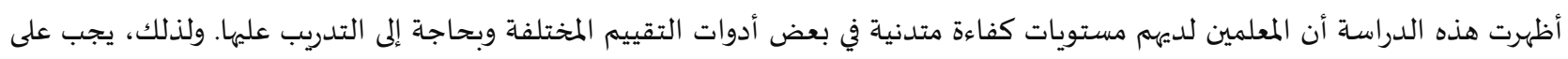

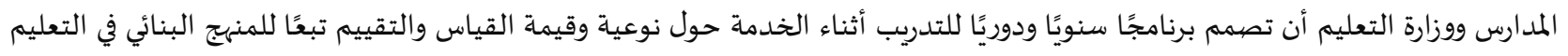
واستخدام أدوات التقييم والقياس المختلفة.

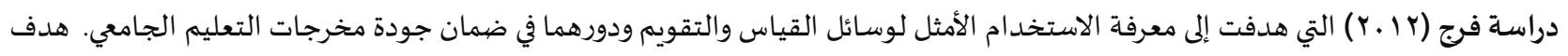

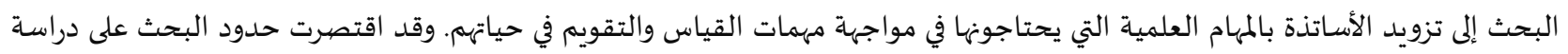

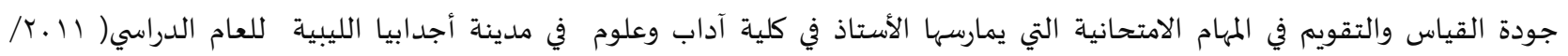

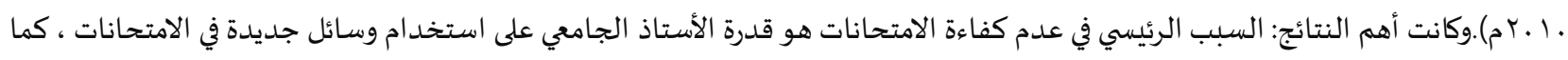

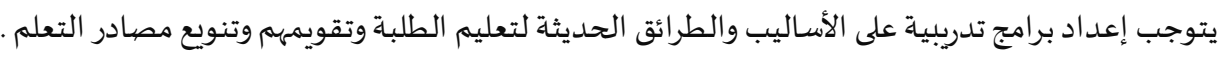

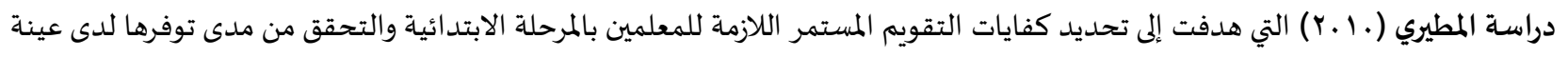

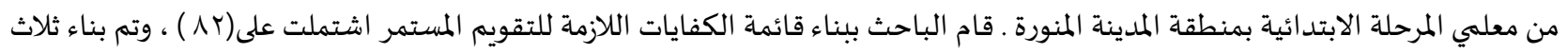




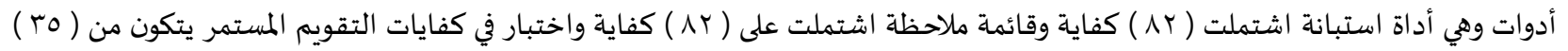

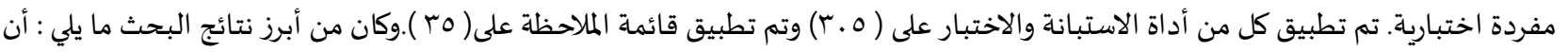

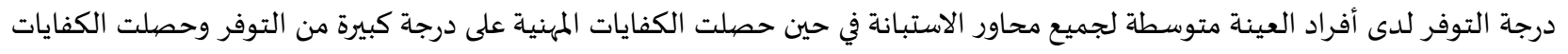
الخاصة باستخدام ملف إنجاز الطالب على درجة " لا يمارسها " من التوفر حسب قائمة الملاحظة ، وتتوفر كفايات تحليل وتفسير نتائج التقويم

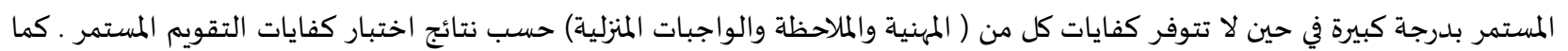
كشفت نتائج البحث عن وجود فروق لصالح بعض التخصصات على بعض محاور الأدوات ، كما كشفت النتائج أنه كلما زادت سنوات الخبات الخبرة لدى

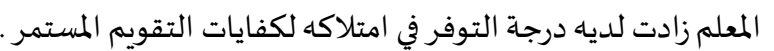

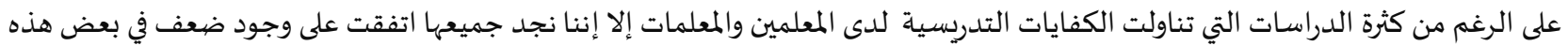
الكفايات وخاصة كفايات القياس والتقويم لذا جاء هذا البحث لوضع قائمة من كفايات القياس والتقويم تسهم في إعداد المعلم، ومساعدة المعلمين على تحسين كفاياتهم في ضوء الكفايات التي ينبغي أن تتوافر لدههم، أيضًا إثراء مجال البحث التربوي في حقل الكفايات التعليمية وخاصية في مجال القياس لدى المعلمين، و مساعدة القائمين على العملية التربوية في تطويرها مستعينين بالنتائج والتوصيات والمقترحات التي توصل إليها

كما حرص الباحثان عند وضع قائمة من كفايات القياس والتقويم على الاطلاع والاستفادة من بعض النماذج العالمية الخاصة بهذا المجال

أولاً : نموذج الولايات المتحدة الأمريكية:

عملت الجمعيات التربوية المهنية في الولايات المتحدة الأمريكية منذ عام ـ99 19 م على تطوير قلاتية قوائم من المعايير الخاصة بالكفايات التي توجب امتلاكها من قبل التربويين، وخاصة المعلمين،

وتقع المعايير الخاصة بالتقويم التي توصلت لها الجمعيات التربوية المهنية في أمريكا في سبعة مجالات هي: American Federation of

.(Teachers National Council on Measurement in Education, National Education Association ,1990) المعيار الأول: المهارة في اختيار وانتقاء أدوات وإجراءات التقويم التي تلائم القرارات التربوية المختلفة. المعيار الثاني: المهارة في تطوير أدوات التقويم الملائمة لاتخاذ القرارات التدريسية. • المعيار الثالث: النتائج التي تتمخض عن أدوات وإجراءات التقويم التي طورها أو قام الآخرون بتطويرها أو تبنيها. المهارة في التطبيق والتصحيح والتفسير. • المعيار الرابع: المهارة في استخدام نتائج التقويم عند اتخاذ القرارات الفردية للطلاب والتخطيط للتدريس وتطوير المناهج وتحسين الأداء العام للمدرسـة. المعيار الخامس: مهارة إعطاء الدرجات وإصدار الأحكام الصادقة المبنية على تقويمهم. المعيار السادس: مهارة نقل نتائج عملية تقويم للطلاب وأولياء الأمور وغيرهم من المهتمين بالتقويم. • المعيار السابع: المهارة في معرفة إجراءات التقويم وتجنب الاستخدامات غير السليمة أو غير الأخلاقية لها.

ثانياً: نموذج النيوزيلاندي: (The New Zealand Qualifications Authority, (NZQA) كما ذُكر في حسين( 11 ـ ب) يوجد في نيوزيلاندا بعض السوزلطاندات المختصة بوضع المعايير الأكاديمية للمعلمين في جميع المجالات التربوية، ويأتي

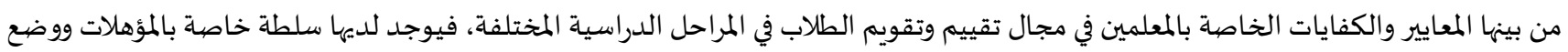

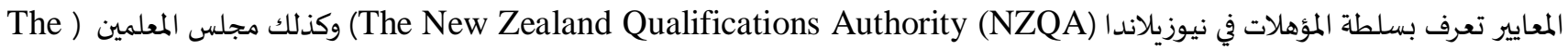
(New Zealand Teachers Council (NZTC الخاصة بذلك إلى السلطة المختصية بالمؤهلات لوضع برامج التنمية المهنية والتدريب للمعلم وفقاً للتقارير والدراسات الميدانية المعدة لذلك.

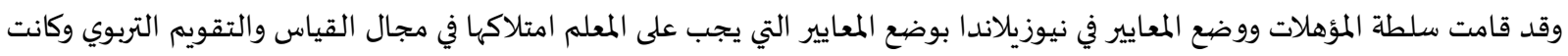

المعيار الأول: يفهم المعلم الهدف من التقويم كمدخل لتحسين التعليم، ويتمكن من تطبيقه، واستخدام أدواته. • المعيار الثاني: يتمكن المعلم من تشخيص حالات التأخر الدراسي، ويضع برامج لعلاجها. ه المعيار الثالث: يتمكن المعلم من اكتشاف التلاميذ المتفوقين، ويضع برامج تنمي تفوقهم. 
ثالثاً: نموذج بريطانيا وويلز: (The Quality Assurance Agency(QAA), 2017, pp 213 - 233 )

شهد العقد الماضي في المملكة المتحدة وويلز تركيزًا كبيرًا من التربويين على أهمية إعادة النظر في أغراض التقويم التربوي، فبعد أن كان التران التركيز

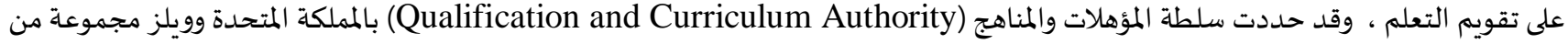

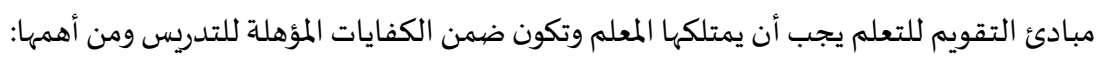

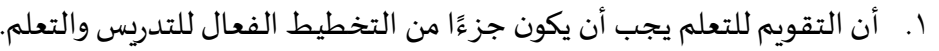

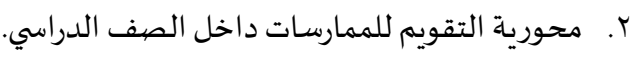
r. اعتبار التقويم مهارة مهنية أساسية للمعلمين.

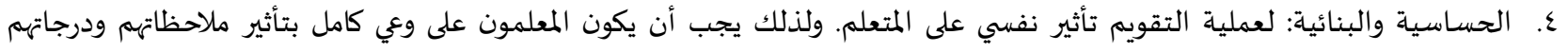
وتقديراتهم على ثقة المتعلمين بأنفسهم وحماسهم للتعلم. 0. دافعية المتعلم: يأخذ التقويم للتعلم في الحسبان أهمية دافعية المتعلم من خلال تشجيع التعلم، وتعزيز الدافعية، والتركيز على التقدم، والإنجاز وليس الفشل. 7. التقويم للتعلم: يجب أن يكون مشجعًا للالتزام بأهداف التعلم، وأن يقدم فهمًا مشتركًا بين جميع المعنيين بالمعايير التي يقوَّم الطالب بناء عليها.

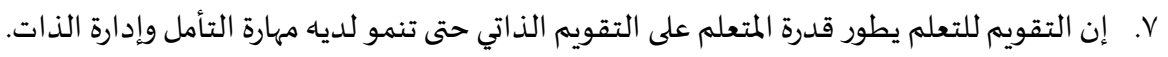

1.إن المتعلمين يجب أن يحصلوا على المعلومات والتوجيهات البناءة حول كيفية تحقيق التحسن في التعلم حتى يخططوا للخطوات القادمة في تعلمهم.

رابعاً: نموذج إندونيسيا كما جاءت في Teaching Competency Standards in Southeast Asian Countries: Eleven Country Audit) Philippine Copyright 2010.

تصنف معايير الكفاءة في التعليم في إندونيسيا إلى أربعة مجالات رئيسية :الكفاءات (التربوية ، الشخصية، المهنية ، الاجتماعية) حيث جاء من ضمن المعايير التربوية ما يخص كفايات القياس والتقويم: يجب أن يكون لدى المعلمين القدرة على تقييم عمليات التعلم والنتائج.

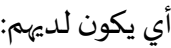
• الخبرة في إجراءات التقويم ، واستخدام نتائج التعلم لتحسين تعلم طابههم.

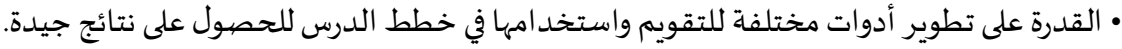
• • القدرة على تطبيق عمليات التقويم لتحديد مدى تعلم الطلاب. • • القدرة على تحليل نتائج التقويم وقدرات طائلاتهم:

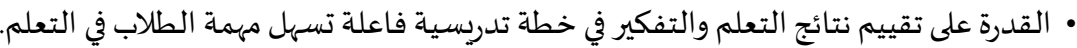
• • القدرة على اتخاذ الإجراءات اللازمة بناء على نتائج التعلم لضمان التئمان الجودة العالية. سادساً: نموذج المملكة العربية السعودية:

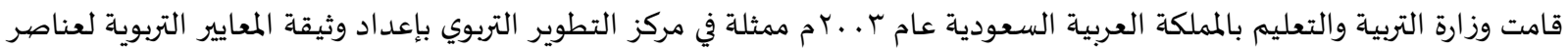

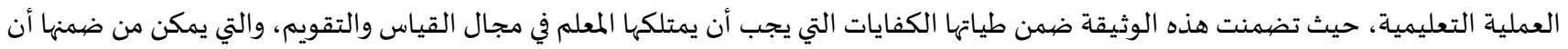

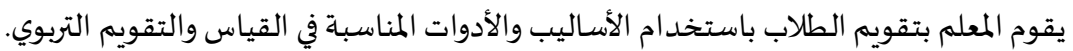
ويجب على المعلم لتحقيق هذا المعيار امتلاك الكفايات التالية: المتطلبات المعرفية: يجب أن يعرف المعلم ويفهم: • مفاهيم وأسس وفوائد القياس والتقويم. • أنواع وأدوات وأساليب القياس والتقويم التربوي وخصائص واستخدامات كل منها. • كيفية تصميم تلك الأدوات شاملة الاختبارات بأنواعها والاستبانات وبطاقات التهات الماتلاحظة ومعايير ذلك. • طرق تحليل وتفسير الدرجات والبيانات والاستفادة من نتائجها.

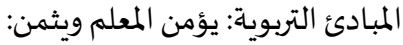


• أهمية القياس والتقويم للعملية التعليمية وفوائدها للطالب وللمعلم. • أهمية تنويع أدوات القياس لتتوافق مع نوعية الأهداف المطلوب قياسها. • ضرورة تفسير البيانات وأهميتها في تحليل عملية التعليم والتغذية الراجعة.

المعايير الأدائية: يعمل المعلم على:

• تشخيص مستويات طلابه للوقوف على معارفهم ومستوياتهم وخبراتهم السابقة. • قياس تحصيل الطلاب لما يتم تقديماه في الدروس اليومية وتوظيف نتائجه. • توضيح معايير وأساليب التقويم التي سيتم استخدامها وشرحها للطلاب. • تنويع أدوات القياس والتقويم من اختبارات مقالية وموضوعية وشفوية وأدائية لتتوافق مع الهدف والمحتوى المطلوب قياس التحصيل فيه. • تصيميم أدوات القياس والتقويم وفق القواعد الصحيحة. • تهيئة الأجواء المناسبة لأداء الاختبارات - وغيرها من أساليب التقويم - من النواحي الحسية والمعنوية. • تصحيح الإجابات بطريقة علمية. • تفسير وتحليل درجات الاختبارات وغيرها وتزويد الطلاب بالتغذية الراجعة عن أدائهم. • تنمية الشعور بالتقويم الذاتي لدى الطلاب وتطوير مهاراتهم في ذلك.

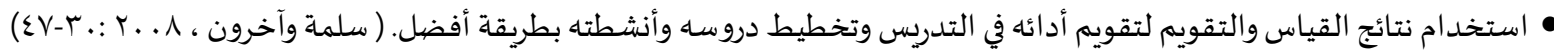
وبعد الاطلاع على نتائج الدراسات السابقة وما أشـارت إليه من وجود انخفاض في مستوى كفايات مختلفة لدى المعلمين بشكل عام وما يخص

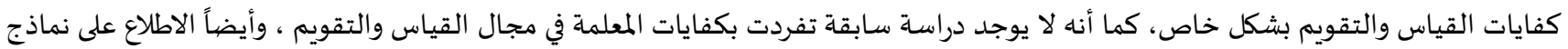
عالمية من المعايير الخاصة بالكفايات التي توجب امتلاكها من قبل المعلمين، جاءت الحاجة لهذه الدراسة والتي تهدف إلى الوصول لمعلومات عن كفايات

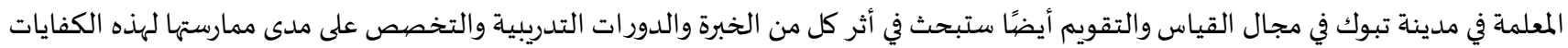

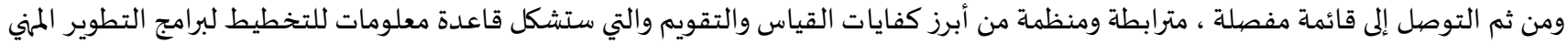
للمعلم وتحسين أدائه وتطوير مهاراته في القياس والتقويم.

مشكلة البحث وتسـاؤلاتها:

من خلال نتائج وتوصيات البحوث السابقة التي تناولت الكفايات لدى المعلمين بشكل عام والقياس والتقويم بشكل خاص جاءت الحاجة الملحة لتحديد كفايات القياس والتقويم لمعلمات المراحل المختلفة (ابتدائي- متوسط- ثانوي ) ومن هنا جاءت مشكلة هذا البحث من خلال الإجابة عن التساؤلات التالية:

ا. ما درجة إدراك كفايات القياس والتقويم لدى معلمة التعليم العام بتبوك وفق المعايير العالمية في ضوء بعض المتغيرات؟

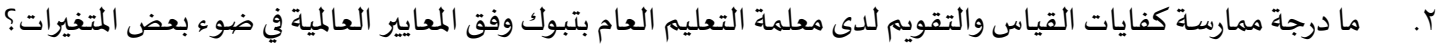

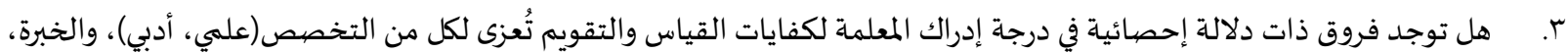

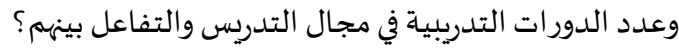

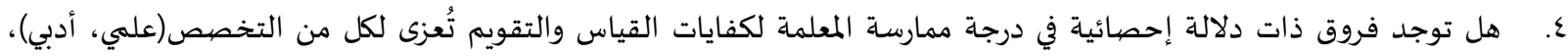
والخبرة، وعدد الدورات التدريبية في مجال التدريس والتفاعل بينهم؟

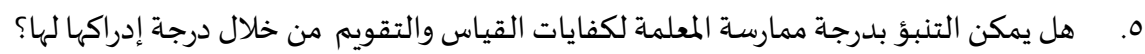

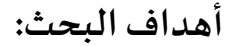

$$
\begin{aligned}
& \text { يسعى هذا البحث إلى تحقيق الأهداف الآتية : } \\
& \text { l. التحقق من درجة إدراك معلمة التعليم العام بتبوك لكفايات القياس والتقويم. } \\
& \text { r. التحقق من درجة ممارسة معلمة التعليم العام بتبوك لكفايات القياس والتقويم. }
\end{aligned}
$$

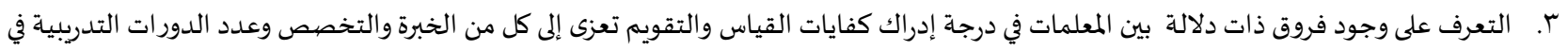
مجال التدريس. 
ع. التعرف على وجود فروق بين المعلمات في درجة ممارسة كفايات القياس والتقويم تعزى إلى كل من الخبرة والتخصص وعدد الدورات التدرببية في مجال

التدريس.

0. التحقق من إمكانية التنبؤ بدرجة ممارسة المعلمة لكفايات القياس والتقويم من خلال درجة إدراكها لها.

أهمية البحثث:

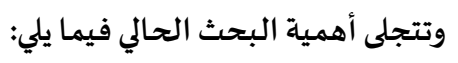

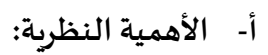

1. أن البحث الحالي مستمد من نماذج عالمية المية للكفايات المهنية للمعلم.

r. أن البحث يسعى إلى تحديد كفايات القياس والتقويم لدى مُعلمة التعليم العام حيث إن امتلاك المعلماتمة لمهارات القياس والتقويم يُحسن

عملية التعليم والتعلم ويطورها.

ب- الأهمية التطبيقية:

ا. . أنه إسهام جديد لبناء بطاقة مقننة لقياس واقع كفايات القياس والتقويم لدى المعلمة بتبوك ومعرفة أوجه القصور واقتراح العلاج المناسب المبات

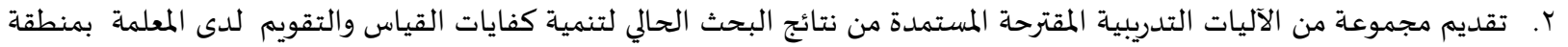

r. أهمية تقويم البرامج التربوية بصفة عامة وأساليب القياس و التقويم الحديثة بصفة خاصة حيث يقدم تغذية راجعة تساعد في عملية الإصلاح والتطوير.

مصطلحات البحث:

الكفاية Competency: القدرة لإنجاز بعض المهام والوظائف والقيام ببعض الأعمال.(الأسـدي وآخرون، 10 ـr؟: ع ا )

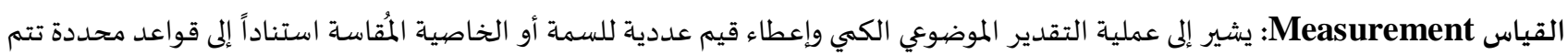

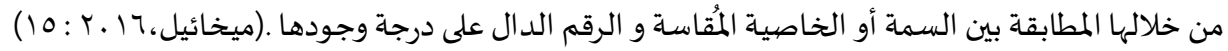

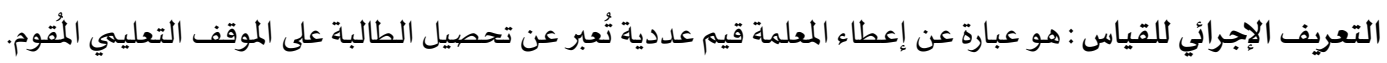

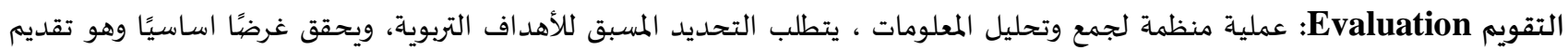

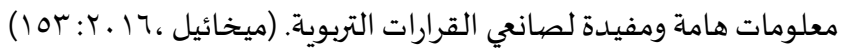
التعريف الإجرائي للتقويم: هو عبارة عن إجراء يتطلب من المعلمة إصدار حكم واتخاذ قرار حول أداء الطالبة للوصيول إلى تحسين التعلم وتحقيق الأهداف التربوية. التعريف الإجرائي لكفايات القياس والتقويم: هي مجموعة من المعارف والمفاهيم والقدرات التي ينبغي أن تمتلكها المعلمة كي تتمكن من القيام بعمليات القياس والتقويم المتعلقة بقياس تحصيل الطالبات بدقة وكفاءة. التعليم العام Public Education: يتضمن التعليم العام ثلاث مراحل تعليمية هي المرحلة الابتدائية والمرحلة المتوسطة والمرحلة

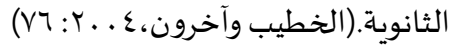
التعريف الإجرائي لمعلمة التعليم العام: هي المعلمة التي تقوم بتدريس مرحلة أو أكثر من مراحل التعليم العام التي تتضمن المرحلة الابتدائية والمرحلة المتوسطة والمرحلة الثانوية. المعايير Standards: تستخدم كلمة معيار بمعنى وجود قاعدة أو مستوى تحدده التوقعات المنتظرة من أفراد معينين في مواقف اجتماعية محددة ،

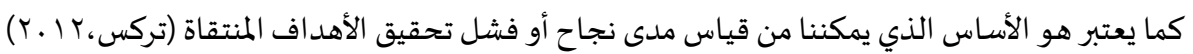
التعريف الإجرائي للمعايير: مجموعة من المحكات للحكم على جودة أداء المعلمة في قياس وتقويم تحصيل الطلبات

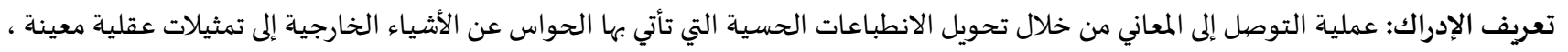

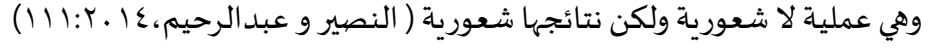

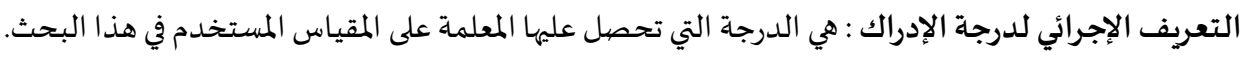

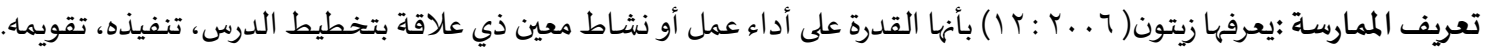
التعريف الإجرائي لدرجة الممارسة : هي الدرجة التي تحصل عليها المعلمة على المقياس المستخدم في هذا البحث. 
حدود البحث: الحددود المكانية : اقتصر البحث على معلمات المراحل ( الابتدائي -المتوسط - الثانوي ) في المدارس التابعة لإدارة التعليم في مدينة تبوك.

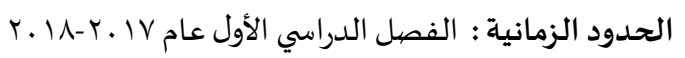
الحدود الموضيوعية : اقتصر البحث على أبرز كفايات القياس والتقويم وفق الاتجاهات المعاصرة دون غيرها من الكفايات التربوية. منهجية البحثث: اتبع الباحثان المنهج الوصفي لملاءمتاه لطبيعة وبيانات البحث.

مجتمع البحث:

يتكون مجتمع البحث من جميع المعلمات بمدارس التعليم العام داخل مدينة تبوك (ابتدائي - متوسط - ثانوي )، التابعة للإدارة العامة

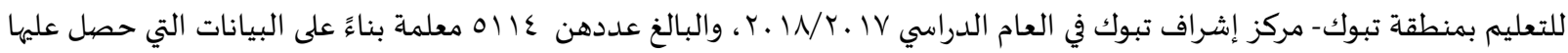

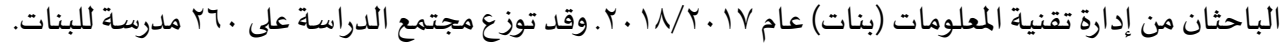
عينة البحث :

يستهدف البحث عينة من جميع المعلمات بمدارس التعليم العام بمدينة تبوك تم اختيارها باتباع أسلوب العينة العشوائية الطبقية. .

أداة البحث : n

لجمع المعلومات والبيانات المتعلقة بالبحث استخدم الباحثان كلاً من :

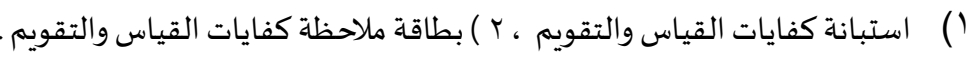

ا ـ استبانة كفايات القياس والتقويم أ) بناء الاستبانة :

1. الفديد الغرض من الاستبانة:

الغرض من الاستبانة هو وضع قائمة من كفايات القياس والتقويم تسهم في إعداد المعلم في البرامج الأكاديمية التي تقدمها كليات التربية

والبرامج التدريبية التي تقدمها الوزارة.

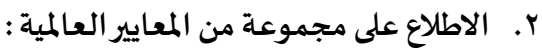

اطلعت الباحثة على مجموعة من المعايير المهنية العالمية العامة والمعايير الخاصة بالقياس والتقويم ،واستخلصت الكفايات التي من الممكن أن تسهم في إعداد المعلم وتطوير كفاياته في القياس والتقويم, وأهم هذه المعايير :

$$
\begin{aligned}
& \text { ا. نموذج المعايير المهنية الأمريكية. } \\
& \text { r. ن نموذج المعايير المهنية في نيوزيلاندي. } \\
& \text { r. نموذج المعايير المهنية في بريطانيا وويلز. }
\end{aligned}
$$

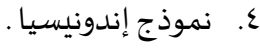

$$
\begin{aligned}
& \text { 0. نموذج استراليا. } \\
& \text { 7. نموذج المملكة العربية السعودياة. } \\
& \text { r. صياغة وبناء فقرات الاستبانة: }
\end{aligned}
$$

مرت عملية بناء أداة الاستبانة بعدة مراحل بدأت بمراجعة الإطار النظري للبحث والذي شمل الدراسات السابقة التي تناولت الكفايات

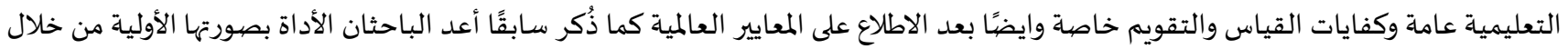
صياغة عدد من العبارات التي تمثل كفايات القياس والتقويم مع مراعاة شروط الصياغة وهي :أن تكون العبارات موضوعية، بسيطة ومكتوبة بلغة

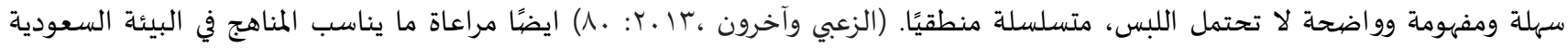

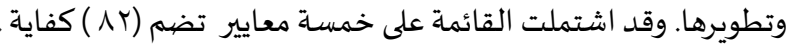

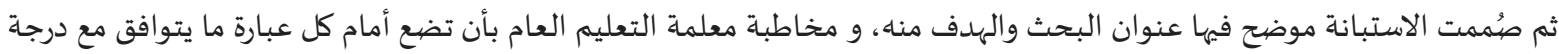
إدراكها للكفاية بكل دقه وموضوعية وفق (مقياس ليكرت الخماسي ) ،( بدرجة كبيرة جداً، بدرجة كبيرة ، بدرجة متوسطة، بدرجة قليلة، لا أدركها)، 
وتأكيد الباحثان أن المعلومات سوف تُستخدم لأغراض البحث العلمي فقط ، كما أهنا موضع اهتمام الباحثان و ذُيل الخطاب بشكر المبحوث سلفاً

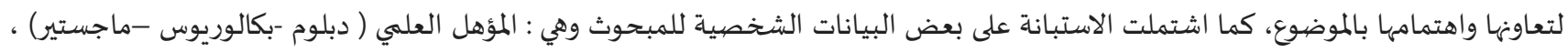

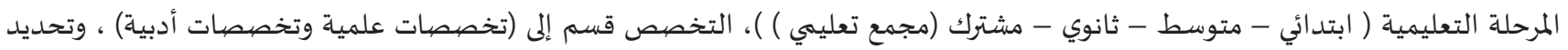

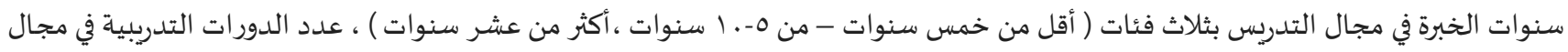

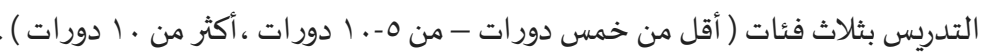

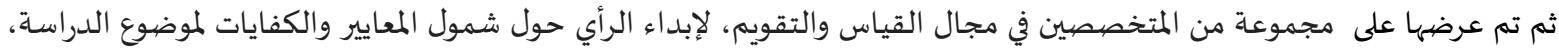
وطريقة صياغتها. ووضوحها ومدى ملاءمة العبارة للبعد الذي تنتهي إليه، و بعد الأخذ بمقترحاتهم وتوصياتهم حول إخراج الأداة في صورتها النهائية والتي

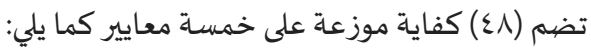

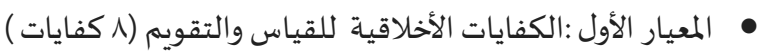

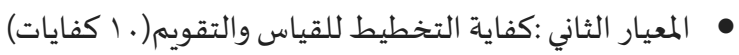

• • • المعيار الثالث : كفاية تنفيذ عملية القياس و التقويم(باكفاية )

• المعيار الرابع: كفاية تفسير نتائج عملية القياس و التقويم (. الكفايات )

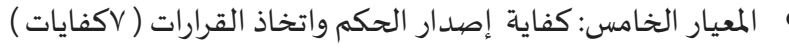

التجريب والتطبيق الأولي للاستبانة على العينة الاستطلاعية :

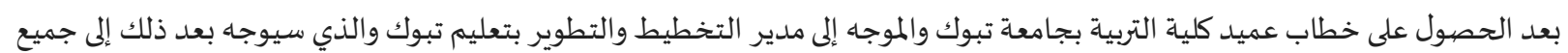
المدارس بالمنطقة (ابتدائي - متوسط- ثانوي) بتسهيل مهمة الباحثة لتطبيق أداة الدراسة حيث تم تجريب الأداة على العينة الاستطالاعية (عشوائية

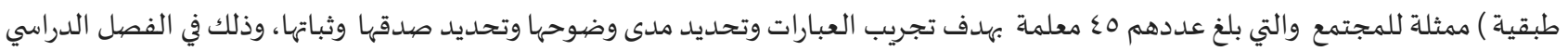

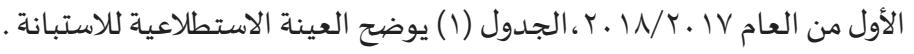

جدول(1): عدد المدارس ومعلمات العينة الاستطلاعية للاستبانة

\begin{tabular}{|c|c|c|c|c|}
\hline المجموع & الثانوي & المتوسط & & المرحلة \\
\hline$r$ & 1 & 1 & 1 & المدارس \\
\hline 纟o & 10 & 10 & 10 & المعلمات \\
\hline
\end{tabular}

صددق الاستبانة :

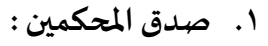

بعد أن تم عرض الأداة على (r ا ) من المحكمين المختصين في التربية والقياس التربوي وطُلب من كل منهم أن يبدي رأيه في مدى مناسبة الفقرات

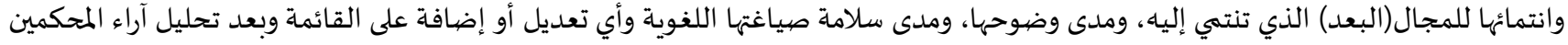

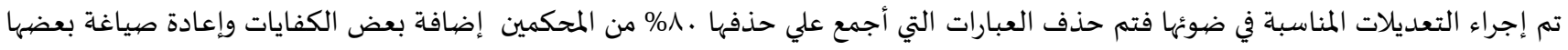

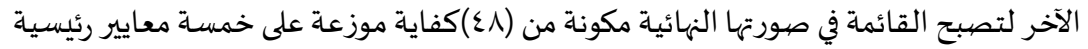

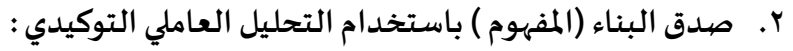

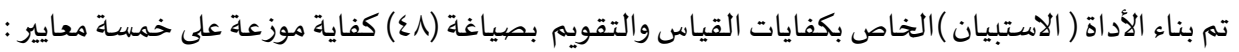

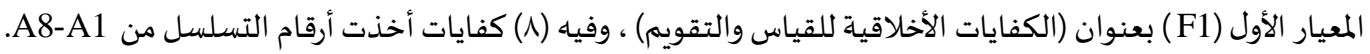

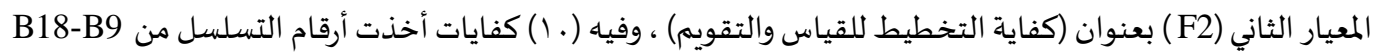

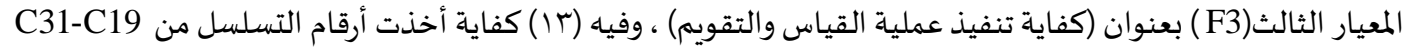

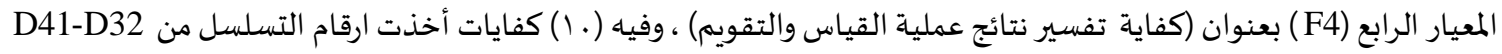

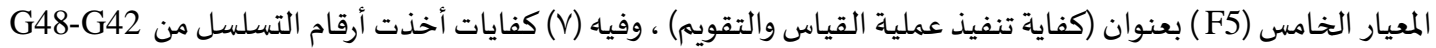
ودخلت العبارات (^乏) بالمحاور الخمسة مرحلة التحليل الإحصائي على النحو الآتي: 
•فحص صدق التكوين العاملي للأداة بدءًا بالنموذج البنائي الفرضي model Hypothetical كما هو موضح في الشكل( ) . الشكل (1): النموذج البنائي الفرضي لاستبانة كفايات القياس والتقويم

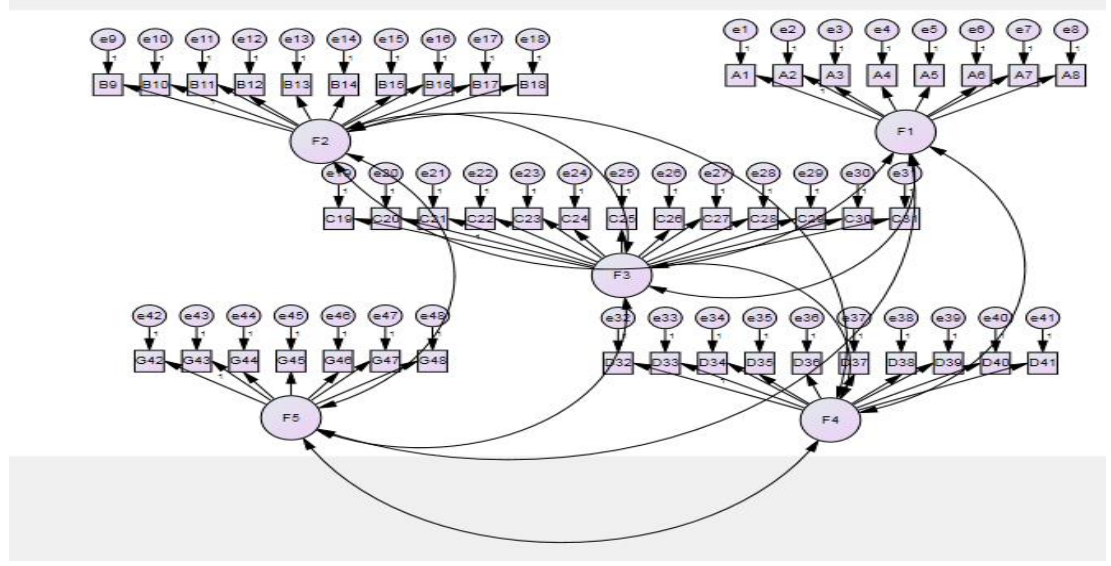

أُدخل هذا النموذج الفرضي في برنامج أموس AMOS للتحليل العاملي التوكيدي Confirmator لتصفية العبارات وفق ثلاثة معايير إحصائية أهمها: (CFA) Factor Analysis

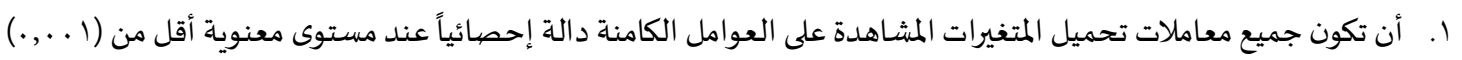

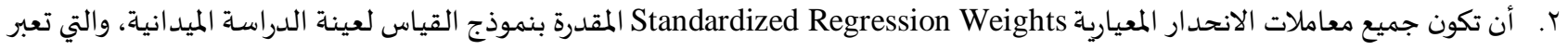

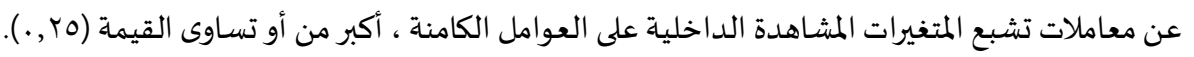

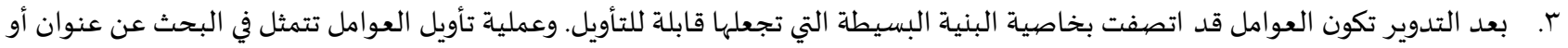

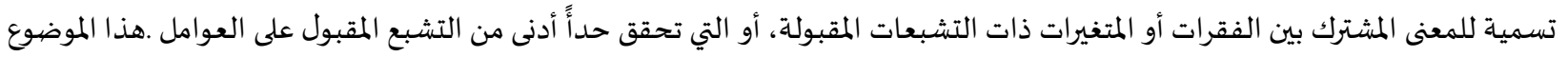

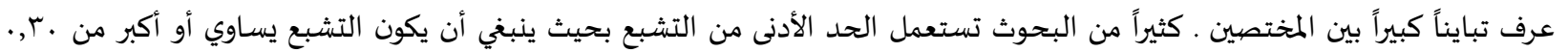

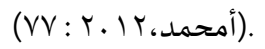
ع. وفي هذا البحث أعتمد الباحثان على أن مربعات معاملات الارتباط Squared Multiple Correlations وهي متوسطات نسبة التباين المُفسر (AVE) Convergent Validity

جدول (Y): توزيع تكراري للكفايات في الأداة الخاصة بكفايات القياس والتقويم حسب مؤشر مربع معاملات الانحدار المستخلصة من التحليل العاملي

\begin{tabular}{|c|c|c|}
\hline \multicolumn{3}{|c|}{ التوكيدي للنموذج الفرضي } \\
\hline أرقام تسلسل العبارات المحذذوفة & عدد العبارات في الفئة & مربعات معاملات الانحدارفي الفئات \\
\hline$r .019 .0 . r$ & $\varepsilon$ & مr ب, . فأقل \\
\hline & IV & $., r q \ldots, r 01$ \\
\hline & 9 &.,$\varepsilon 9-, ., \varepsilon$. \\
\hline & r &., $09-., 0$. \\
\hline & 7 & $\cdot, 79-\cdot, 7$ \\
\hline & 9 & 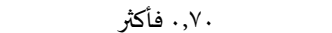 \\
\hline
\end{tabular}

وتوزعت العبارات المحذوفة الآتية(المشار إلمها في الجدول حسب المعيار المعتمد للحذف):

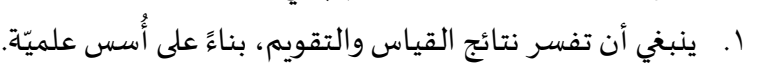
r. الحرص على الموضوعية عند تطبيق أدوات القياس والتقويم، وعند تقدير درجاتها، وتئ، وتفسير نتائجها. r. اختيار مواعيد التقويم بما يتناسب مع ظروف الطالبات.

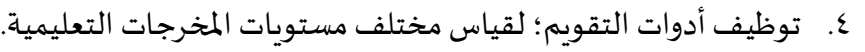
وكانت أرقام الفقرات المحذوفة في المحاور حسب التسلسل الرقمي لها في المقياس عند التطبيق على النحو الآتي: 


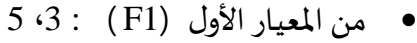

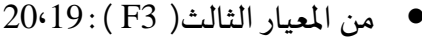

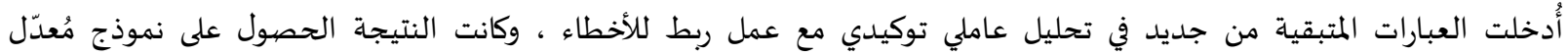

Parsimonious Model

الشكل (r): النموذج البنائي المعدل Parsimonious Model لاستبانة كفايات القياس والتقويم.

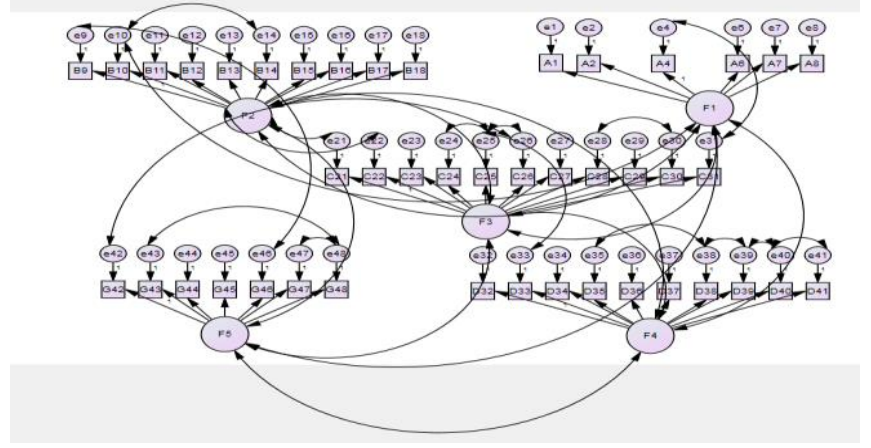

Squared Multiple Correlations وباعتماد معيار مربعات معاملات الارتباط

ومعاملات الانحدار المعيارية Standardized Regression Weights المستخلصة كانت جميع العبارات المتبقية في المحور الواحد محققة

لذلك المعيار وجميعها ذات دلالة إحصائية عالية.

جدول (r): توزيع تكراري للعبارات في مقياس السلوكيات حسب مؤشر مربع معاملات الانحدار المستخلصية من التحليل العاملي التوكيدي للنموذج المعدّل

\begin{tabular}{|c|c|c|c|c|c|c|c|c|c|}
\hline الإنحدارية & معاربات & ملف البيانات & ملف البيانات حسبب العبارة في & رقم المحور & الالإنحدارية & مربعات & ملف البيانات حسب النمبـ & ملف البيانات & رقم المححور \\
\hline ,,$\lambda r$ &., 79 & Q28 & D32 & F4 & , Tr & , ro & Q1 & A1 & F1 \\
\hline., 79 & ., \&A & Q29 & D33 & F4 &., 01 & . & Q2 & $\overline{\mathrm{A2}}$ & F1 \\
\hline.,$\lambda 1$ &., 71 & Q30 & D34 & F4 &., 09 &.,$r \varepsilon$ & Q3 & A4 & F1 \\
\hline . Ar & . TV & Q31 & D35 & F4 &.,$V Y$ & . & Q4 & A6 & F1 \\
\hline., 17 &., $\mathrm{~V} \varepsilon$ & Q32 & D36 & F4 &., 09 &.,$\mu \varepsilon$ & Q5 & A7 & F1 \\
\hline., $\mathrm{rA}$ &., 71 & Q33 & D37 & F4 & ., or & . & Q6 & A8 & F1 \\
\hline . 9 , &., 10 & Q34 & D38 & F4 & . Or &., $\mathrm{rV}$ & Q7 & B9 & F2 \\
\hline., 19 & . $\mathrm{va}$ & Q35 & D39 & F4 & . \&o & . r. & Q8 & B10 & F2 \\
\hline . .17 &., $\mathrm{Vr}$ & Q36 & D40 & F4 & . $\varepsilon V$ &.,$r Y$ & Q9 & B11 & F2 \\
\hline., 19 &., $\mathrm{Vq}$ & Q37 & D41 & F4 & ., or &.,$r v$ & Q10 & B12 & F2 \\
\hline . &., $\mathrm{rq}$ & Q38 & G42 & F5 &., $0 \mathrm{~V}$ &.,$\pi r$ & Q11 & B13 & F2 \\
\hline., $\mathrm{Vr}$ & , or & Q39 & G43 & F5 &.,$\sum 7$ &. & Q12 & B14 & F2 \\
\hline., 79 & ., \&A & Q40 & G44 & F5 & . है &.,$\pi r$ & Q13 & B15 & F2 \\
\hline.,$V_{1}$ &., 01 & Q41 & G45 & F5 &., $7 \varepsilon$ & 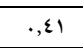 & Q14 & B16 & F2 \\
\hline , 71 & ., \&V & Q42 & G46 & F5 &., $0 \varepsilon$ &.,$r 9$ & Q15 & B17 & F2 \\
\hline , &., 49 & Q43 & G47 & F5 &., 79 &.,$\varepsilon \wedge$ & Q16 & B18 & F2 \\
\hline \multirow[t]{11}{*}{., $7 \varepsilon$} & .,\&l & Q44 & G48 & F5 & . &.,$r 9$ & Q17 & C21 & F3 \\
\hline & & & & & . 70 & . & Q18 & $\mathrm{C22}$ & F3 \\
\hline & & & & &.,$\varepsilon 9$ &., $\mathrm{r}$ & Q19 & $\mathrm{C23}$ & F3 \\
\hline & & & & &., 79 &.,$\varepsilon 9$ & Q20 & C24 & F3 \\
\hline & & & & &., $7 \varepsilon$ & . $\varepsilon Y$ & Q21 & $\mathrm{C25}$ & F3 \\
\hline & & & & & ., AI &., 70 & Q22 & C26 & F3 \\
\hline & & & & & .,Ar &., 71 & Q23 & C27 & F3 \\
\hline & & & & &., 94 &., 10 & Q24 & $\mathrm{C28}$ & F3 \\
\hline & & & & &., $\mathrm{V} r$ & , or & Q25 & C29 & F3 \\
\hline & & & & &., $9 \varepsilon$ &., 19 & Q26 & C30 & F3 \\
\hline & & & & & $\cdot, \wedge$ &., $\mathrm{VV}$ & Q27 & C31 & F3 \\
\hline
\end{tabular}


ثبات الاستبانة :

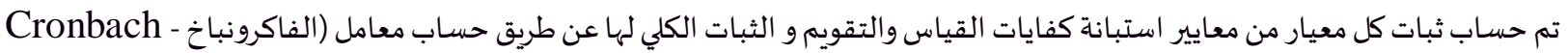
والتجزئة النصفية عن طريق حساب معامل (سبيرمان براون - Spearman Brown ، وجتمان-Guttman) على العينة الاستطلاعية.

جدول (ع): ثبات كل محور من محاور الاستبانة والثبات الكلي للاستبانة

\begin{tabular}{|c|c|c|c|c|c|}
\hline \multicolumn{4}{|c|}{ ق قيم معامل الثبات } & \multirow[t]{2}{*}{ المعيار } & \\
\hline جتمان & سبيرمان براون & قيمة معامل ألفا كرونباخ & عدد الفقرات & & \\
\hline . , , o & $\cdot, \mathrm{V} 7$ &., ,o & 7 & الكفايات الأخلاقية للقياس والتقويم & .1 \\
\hline . ג & . ג r & , AV & 1. & كفاية التخطيط للقياس والتقويم & r \\
\hline., 07 & . TV &.,$\wedge \varepsilon$ & 11 & كفاية تنفيذ عملية القياس و التقويم & r \\
\hline . AT & .人t & . ה & 1. & كفاية تفسير نتائج عملية القياس والتقويم & $\varepsilon$ \\
\hline.,$\Lambda$ & $\cdot, \wedge 9$ &., 91 & $\mathrm{v}$ & كفاية إصدار الحكم واتخاذ القرارات & .0 \\
\hline$\cdot, 10$ &,, 10 &., 90 & $\varepsilon \varepsilon$ & الاستبانة ككل & \\
\hline & & & ن = 0. & & \\
\hline
\end{tabular}

ويتضح من الجدول (ع) أعلاه أن الثبات الكلي للاستبانة وفق قيمة معامل ألفا كرونباخ للاستبانة ككل (

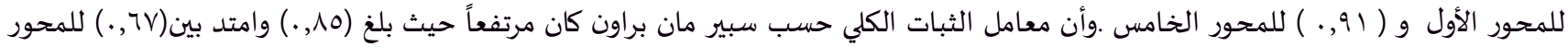

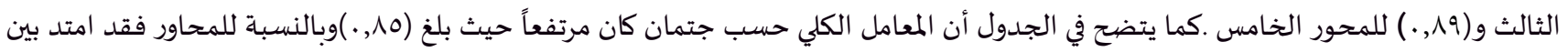
(7ه , .) للمحور الثالث و(1), .) للمحور الخامس .كما نلاحظ أن نتيجة معامل الثبات الكلي مرتفعة في جميع الطرق التي حسبناها.

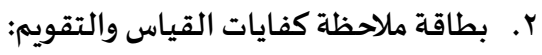

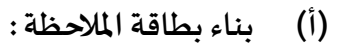

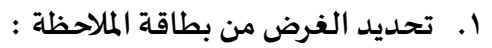

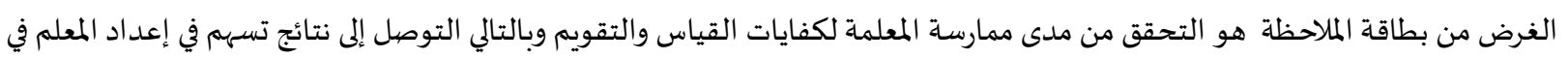

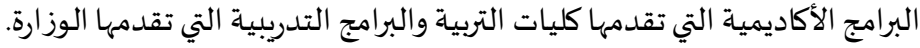

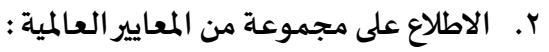

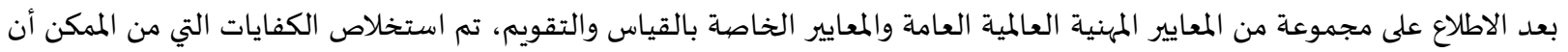
تسهم في إعداد المعلم وتطوير كفاياته في القياس والتقويم, وأهم هذه المعايير : 1. أنموذج المعايير المهنية الأمريكية. r. - بموذج المعايير المهنية في نيوزيلاندي. r. نموذج المعايير المهنية في بريطانيا وويلز. ع. نموذج إندونيسيا كما جاءت في.

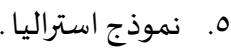

7. نموذج المملكة العربية السعودية.

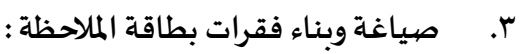

مرت عملية بناء بطاقة الملاحظة بنفس الخطوات السابقة التي مرت بها عملية بناء الاستبانة إلا أن الفرق كان في اختيار العبارات التي يكون فيها

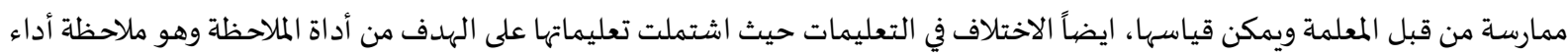

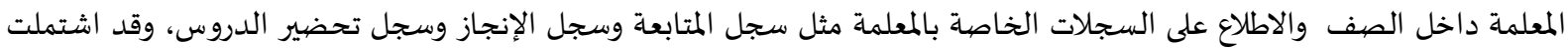
بطاقة الملاحظة في صورتها النهائية والتي تضه (Tع) كفاية موزعاة على خمسة معايير كما يلي: 
المعيار الأول :الكفايات الأخلاقية للقياس والتقويم (0 كفايات )

المعيار الثاني :كفاية التخطيط للقياس والتقويم(·ل كفايات)

المعيار الثالث : كفاية تنفيذ عملية القياس و التقويم(الكفاية )

المعيار الرابع: كفاية تفسير نتائج عملية القياس و التقويم (. المفايات )

المعيار الخامس: كفاية اصدار الحكم واتخاذ القرارات ( Vكفايات )

حيث تم تحديد المعلمة المستهدفة بالملاحظة ومن ثَم زيارتها في الحصة الدراسية والتسجيل في بطاقة الملاحظة ما تم ملاحظته من أداء المعلمة

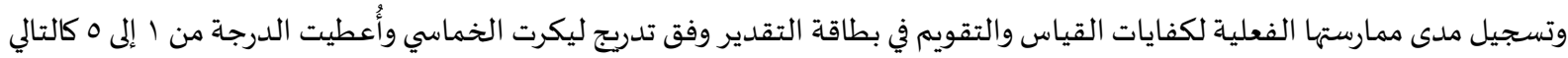

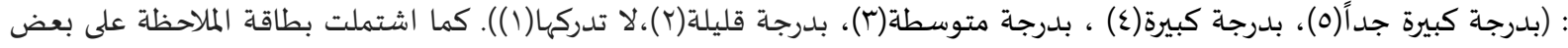

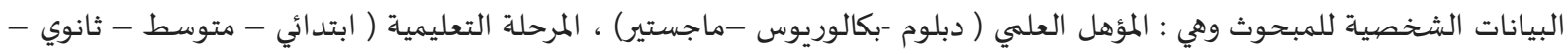

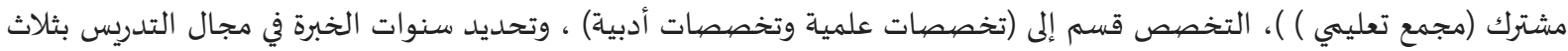

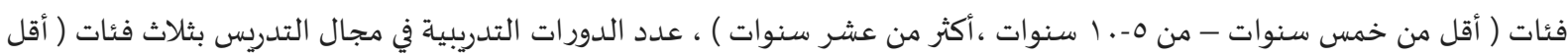

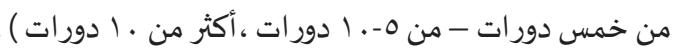

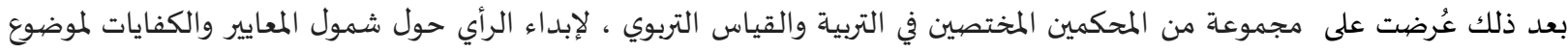
البحث، وطريقة صياغتها. ووضوحها ومدى ملاءمة العبارة للبعد الذي تنتهي إليه، و بعد الأخذ بمقترحاتهم وتوصياتهم تم إخراج الاداة في

صورتها النهائية .

ع. التجريب والتطبيق الأولي لبطاقة الملاحظة على العينة الاستطلاعية:

بعد الحصول على خطاب عميد كلية التربية بجامعة تبوك والموجه إلى مدير التخطيط والتطوير بتعليم تبوك والذي سيوجاء بعد ذلك إلى جميع

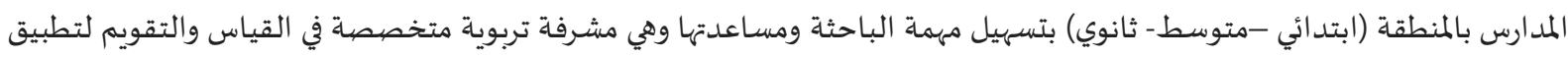

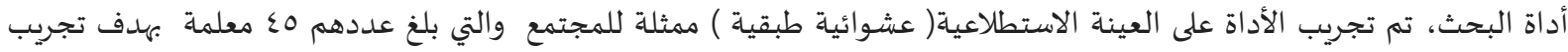

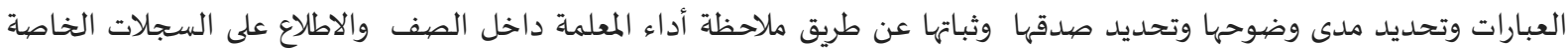
بالمعلمة مثل سجل المتابعة وسجل الإنجاز وسجل تحضير الدروس ومن ثم تعبئة البطاقة بالاتفاق بين الملاحظتين على الدرجة المعطاة لكل

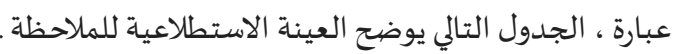

جدول(0): عدد المدارس ومعلمات العينة الاستطلاعية للملاحظة

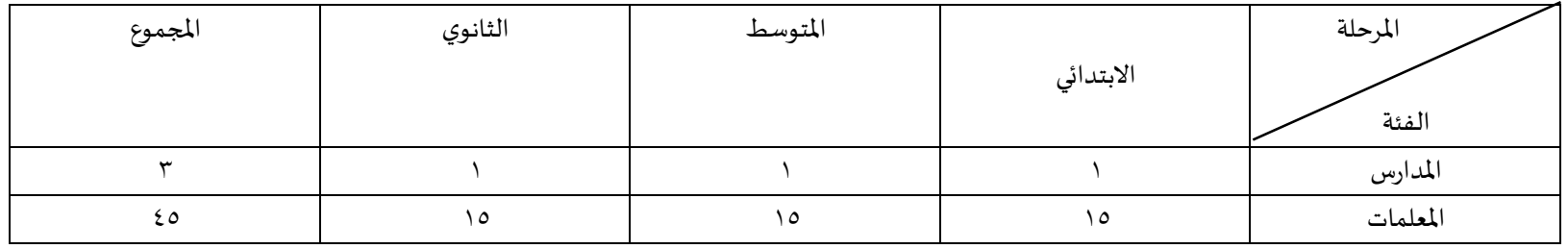

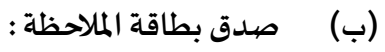

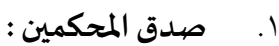

كما مر بنا فإن فقرات بطاقة الملاحظة مُستقاه من فقرات الاستبانة والتي تم تحكيمها من عدد من المحكمين المختصين في التربية والقياس التربوي كما تم الأخذ بجميع توجيهاتهم ومقترحاتهم من الحذف والتعديل والإضيافة.

(ج) ثبات بطاقة الملاحظة:

قامت الباحثة بحساب معامل ثبات كل معيار من معايير بطاقة الملاحظة كفايات القياس والتقويم و الثبات الكلي لها عن طريق معامل

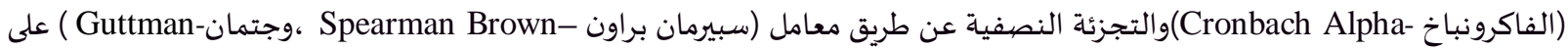

العينة الاستطلاعية . 


\begin{tabular}{|c|c|c|c|c|}
\hline \multicolumn{4}{|c|}{ 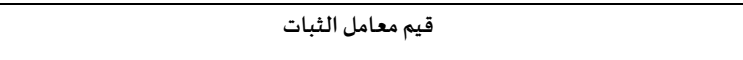 } & \multirow[t]{2}{*}{ 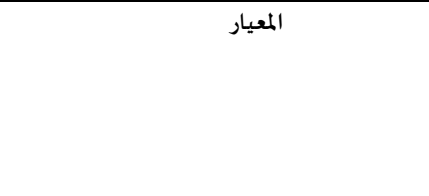 } \\
\hline جتمان & سبيرمان براون & قيمة معامل ألفا & عدد الفقرات & \\
\hline$\cdot, \wedge \mathrm{V}$ & $\cdot, 91$ & $\cdot, 9 \varepsilon$ & $\circ$ & 1. الكفايات الأخلاقية للقياس والتقويم \\
\hline$\cdot, \wedge 7$ & $\cdot, \wedge$ & $\cdot, 9 \varepsilon$ & 1. & كفاية التخطيط للقياس والتقويم \\
\hline$\cdot, \wedge$ & , ג & $\cdot, 94$ & 11 & r. . كفاية تنفيذ عملية القياس و التقويم \\
\hline$\cdot, \mathrm{V} \varepsilon$ & $\cdot, \wedge 7$ & $\cdot, \wedge \varepsilon$ & 1. & ع. كفاية تفسير نتائج عملية القياس والتقويم \\
\hline$\cdot, 9 \varepsilon$ &., 97 & $\cdot, 91$ & v & 0. كفاية إصدار الحكم واتخاذ القرارات \\
\hline., $9 \varepsilon$ &., $9 \varepsilon$ &., 91 & $\varepsilon r$ & بطاقة الملاحظة ككل \\
\hline & & & $\varepsilon_{0}=0$ & \\
\hline
\end{tabular}

ويتضح من الجدول (7) أعلاه أن الثبات الكلي لبطاقة الملاحظة وفق قيمة معامل ألفا كرونباخ للملاحظة ككل(^و,..) وامتدت قيمته للمعايير بين

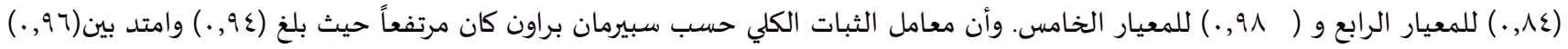

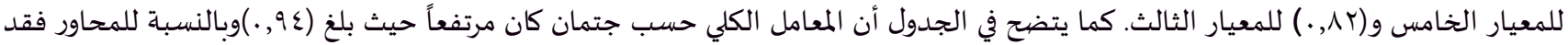

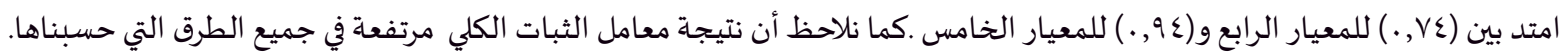

رابعاً : تطبيق أدوات الدراسة: تطبيق الاستبانة وبطاقة الملاحظة على العينة الأسساسية :

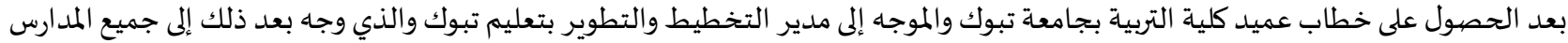

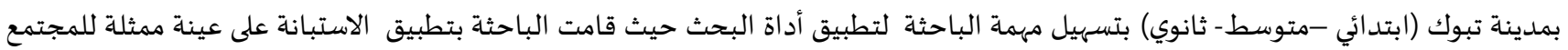

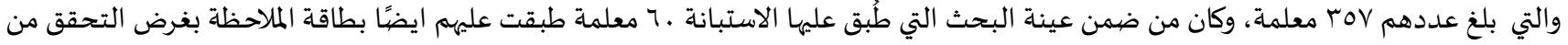

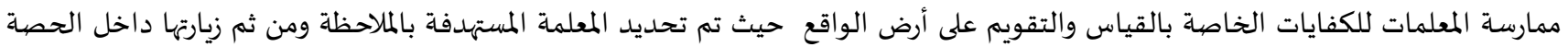

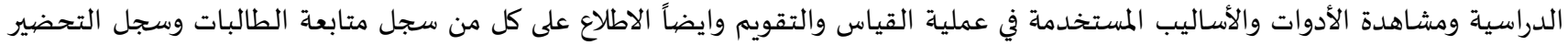
وسجل إنجاز المعلمة ومن ثم رصد ما تم ملاحظته وفق تدريج بطاقة الملاحظة ، وذلك في نهاية شهر صفر خلادل العام الدراسي الأول من العام الدراسي . T. MN/T.IV

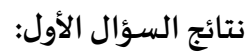
للإجابة عن التساؤل الأول والذي نصال " ما درجة إدراك كفايات القياس والتقويم لدى معلمة التعليم العام بتبوك وفق المعايير العالمية في ضوء

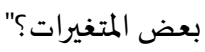
بناء على استجابات عينة الدراسة على استبانة كفايات القياس والتقويم وفقاً لمقياس ليكرت الخماسي تم الحكم على درجة إدراك المعلمة لكفايات القياس والتقويم وفق المستويات التالية :

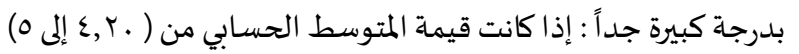

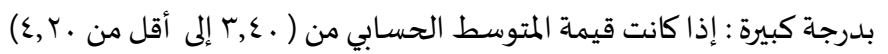

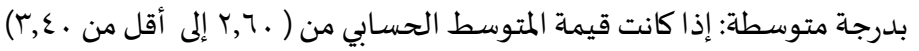

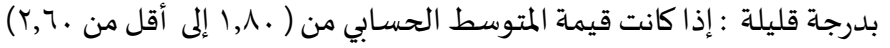

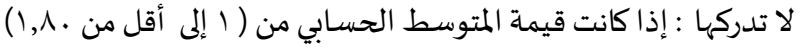
تم بعد ذلك حساب الأوساط الحسابية والانحرافات المعيارية على مستوى الاستبيان الكلي والمعايير، وكذلك على مستوى الكفاية الواحدة في المانيا المعيار

1. على مستوى الأداة ككل : تم إيجاد المتوسط الحسابي والانحراف المعياري لإجابات أفراد العينة حسب معايير الكفايات كما في الجدول(V). 
جدول (V): المتوسط الحسابي والانحراف المعياري لإجابات أفراد العينة حسب معايير الكفايات

\begin{tabular}{|c|c|c|c|c|c|c|c|}
\hline درجة التوافر & درجة الالتواء & الانحراف المعياري & الترتيب & الحسابي & 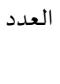 & المعيار & 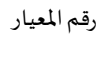 \\
\hline كبيرة & $\cdot, 9 \vee-$ & $\cdot, 7 \mathrm{~V}$ & 1 & $\varepsilon, i r$ & 1 & الكفايات الأخلاقية للقياس والتقويم & الأول \\
\hline 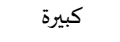 & $\cdot, 79-$ & $\cdot, \mathrm{vr}$ & $\varepsilon$ & $\varepsilon, \cdot r$ & 1. & كفاية التخطيط للقياس والتقويم & الثاني \\
\hline كبيرة & ., Yo- & $\cdot, \mathrm{M}$ & r & $\varepsilon, \cdot r$ & 11 & كفاية تنفيذ عملية القياس و التقويم & الثالث \\
\hline كبيرة & . ו- & $\cdot, \wedge \varepsilon$ & 0 & $r, 79$ & 1. & كفاية تفسير نتائج عملية القياس والتقويم & الرابع \\
\hline كبيرة & ., Y५- & $\cdot, \mathrm{rA}$ & r & $\varepsilon, .0$ & $\mathrm{v}$ & كفاية إصدار الحكم واتخاذ القرارات & الخامس \\
\hline كبيرة & .,Vr- &., 71 & \multicolumn{2}{|c|}{$r, q \vee$} & $\varepsilon \varepsilon$ & \multicolumn{2}{|l|}{ الكـل } \\
\hline
\end{tabular}

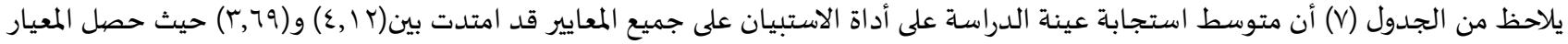

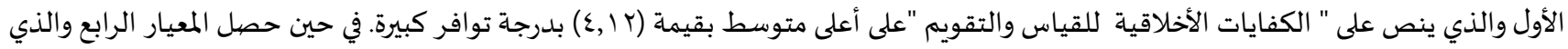

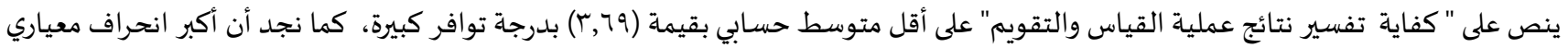

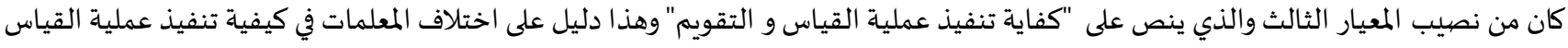

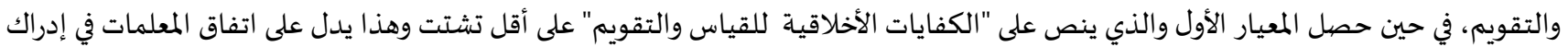
هذه الكفايات وأهميتها بالنسبة لعملية القياس والتقويم.

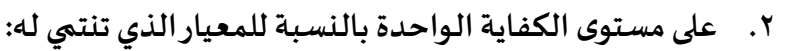
جدول (^): المتوسط الحسابي والانحراف المعياري لإجابات أفراد العينة حسب لإنائ

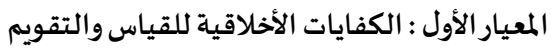

\begin{tabular}{|c|c|c|c|c|c|}
\hline \multicolumn{6}{|c|}{ المعيار الأول :الكفايات الأخلاقية للقياس والتقويم } \\
\hline درجة التوافر & الانحراف المعياري & الترتيب & المتوسط & 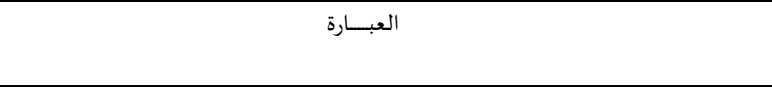 & 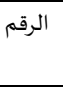 \\
\hline كبيرة &., 99 & $\circ$ & $r, \Lambda \Lambda$ & أن أدوات القياس و التقويم ماهي إلا وسائل؛ لتحسين التعلم وليست غاية في حد ذاتها . & Q1 \\
\hline كبيرة & $1, \cdot r$ & 7 & $r, 70$ & أعطت عملية القياس والتقويم مجالاً متسعاً من الحرية للإبداع في طرائق التدريس. & Q2 \\
\hline كبيرة &., $9 \varepsilon$ & $\varepsilon$ & $\varepsilon, 1 \varepsilon$ & ضرورة التعامل مع المعلومات، والنتائج الفردية للطالبات بسرية تامة. & Q3 \\
\hline كبيرة جداً & $\cdot, \mathrm{V7}$ & 1 & $\varepsilon, 0$. & التحلي بالأمانة عند الاستشهاد بالأدلة ، وإصدار الحكم بعيداً عن التحيز. & Q4 \\
\hline كبيره جداً & $\cdot 97$ & r & $\varepsilon, \uparrow$. & قياس السلوك عند المتعلمين في مناخ إنساني مُفْعَمٌ بالود، والتعاطف بعيد عن الخوف والتوتر. & Q5 \\
\hline كبيرة جداً & $\cdot, \wedge \vee$ & r & $\varepsilon, \Gamma$ & الحرص على مراعاة الفروق الفردية بين الطالبات أثناء العملية التعليمية & Q6 \\
\hline
\end{tabular}

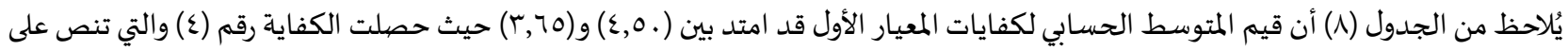

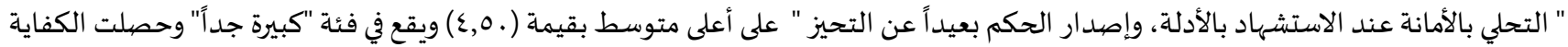

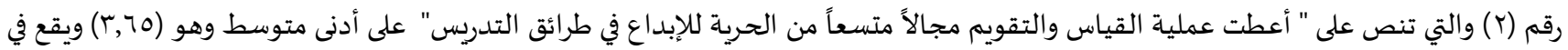

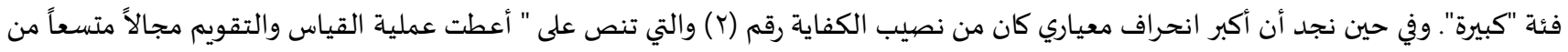

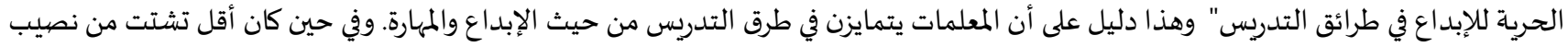

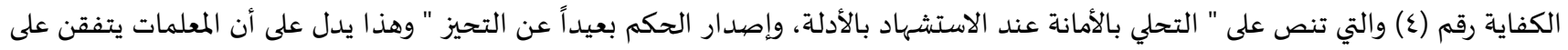
إدراك أهمية الموضوعية في الأحكام والبعد عن التحيز. 
جدول (9): المتوسط الحسابي والانحراف المعياري لإجابات أفراد العينة حسب المعيار الثاني: كفاية التخطيط للقياس والتقويم

\begin{tabular}{|c|c|c|c|c|c|}
\hline \multicolumn{6}{|c|}{ المعيار الثاني :كفاية التخطيط للقياس والتقويم. } \\
\hline 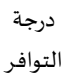 & الانحراف المعياري & الترتيب & المستوسط & 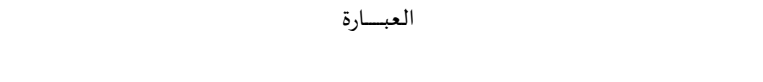 & 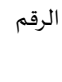 \\
\hline كبيرة & $\cdot, 9 \varepsilon$ & $\varepsilon$ & $\varepsilon, . \wedge$ & المعرفة بأنواع التقويم القبلي، والبنائي، و الختامي . & Q7 \\
\hline كبيرة &., 94 & 7 & $r, 91$ & الربط بين طرائق التدريس المستخدمة، وأساليب القياس. & Q8 \\
\hline كبيرة & $\cdot, 94$ & $\checkmark$ & $r, q$. & إعداد خطط واضحة وشاملة العناصر؛ لعملية القياس. & Q9 \\
\hline كبيرة & $\cdot, \wedge$ & 1 & $\varepsilon, 1 V$ & أهمية تحديد الغرض الذي من أجله تمت عملية التقويم. & Q10 \\
\hline كبيرة & $\cdot, 9$. & r & $\varepsilon, 17$ & مراعاة حاجات الطالبات، وخصائصهم النمائية عند التخطيط في غرفة الصف، وأثناء & Q11 \\
\hline 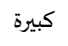 & $\cdot, 9$ & 1 & $\varepsilon, 1 V$ & الحرص على شمولية التقويم لمختلف مجالات التعلم من:(معارف، مهارات، قيم، اتجاهات) . & Q12 \\
\hline 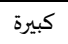 & $1, . r$ & 9 & $r, v q$ & جدول المواصفات بمثابة الدليل في عملية بناء الاختبار. & Q13 \\
\hline كبيرة & $1, \cdot r$ & $\wedge$ & r,人 & 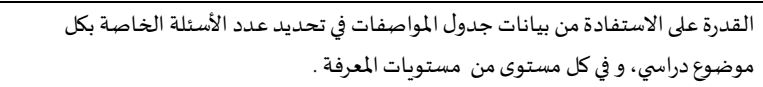 & Q14 \\
\hline كبيرة & .,9r & $r$ & $\varepsilon, 1$. & 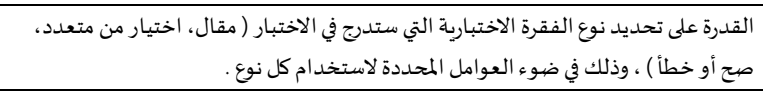 & Q15 \\
\hline كبيرة &., 94 & 0 & $\varepsilon, \cdot r$ & تحديد مستوى الصعوبة المقبولة للفقرات عند بناء الاختبار . . & Q16 \\
\hline
\end{tabular}

يُلاحظ من الجدول (9) أن قيم المتوسط الحسابي لكفايات المعيار الثاني قد امتد بين (Y, IV) و(Y,V9) حيث حصلت الكفايتين رقم (. () والتي

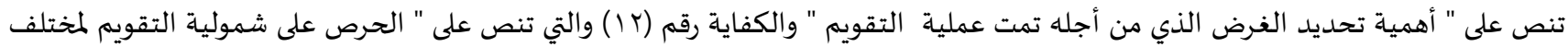

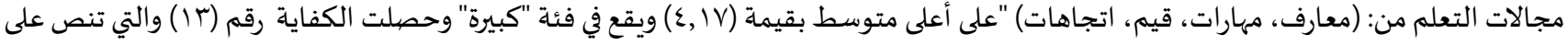

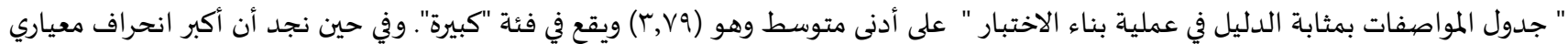

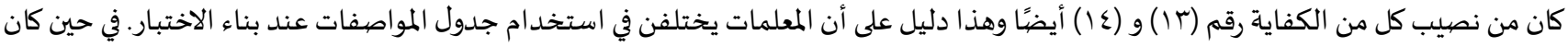

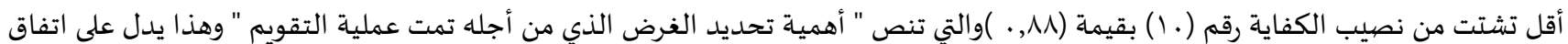

المعلمات على أهمية هذه الكفاية.

جدول ( ـ (): المتوسط الحسابي والانحراف المعياري لإجابات أفراد العينة حسب المعيار الثالث : كفاية تنفيذ عملية القياس و التقويم

\begin{tabular}{|c|c|c|c|c|c|}
\hline & & & & المعيار الثالث : كفاية تنفيذ عملية القياس و التقو & \\
\hline درجة التوافر & الانحراف المعياري & الترتيب & المتوسط الحسابي & العبــارة & 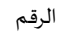 \\
\hline كبيرة &.,$\wedge 9$ & $\mathrm{r}$ & $r, १ \wedge$ & إعداد وتجهيزز كل ما يلزم لعملية القياس؛ لتسهيل طرق تنفيذه. & Q17 \\
\hline كبيرة & $\cdot, \wedge 9$ & $\wedge$ & $r, 90$ & العوامل المحددة لذلك ألتوي المناسبة لظروف الموقف التقويمي، وذلك بحسب & Q18 \\
\hline كبيرة & $\cdot, \mu$ & r & $\varepsilon, 11$ & 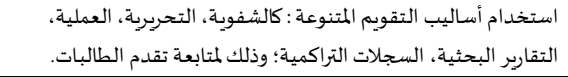 & Q19 \\
\hline كبيرة & $\cdot, \wedge 9$ & . & $\varepsilon, .0$ & 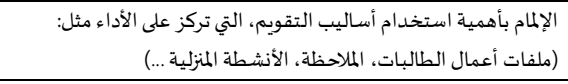 & Q20 \\
\hline كبيرة جداً & $\cdot, \mathrm{rA}$ & 1 & $\varepsilon, r\rceil$ & التكميل، مزاوجة ). & Q21 \\
\hline كبيرة & $\cdot, \wedge)$ & r & $\varepsilon, 1 \varepsilon$ & 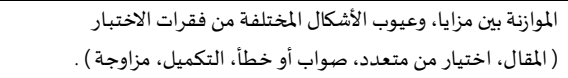 & Q22 \\
\hline كبيرة & $\cdot, \wedge 9$ & $\varepsilon$ & $\varepsilon, 1$. & تشجيع الطالبات على التقويم الذاتي. & Q23 \\
\hline كبيرة & $1, .9$ & 11 & $r, v$. & 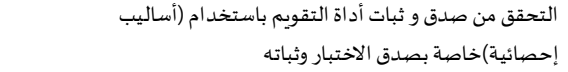 & Q24 \\
\hline كبيرة & $1, \ldots$ & 1. & $r, q 1$ & كتابة إرشادات محددة؛ لتنفيذ أداة التقويم بشكل واضح يسهل اطلاع & Q25 \\
\hline كبيرة &., 94 & 7 & $r, 99$ & المهارة في إخراج أداة التقويم بصورتها الههائية . & Q26 \\
\hline كبيرة & $1, .1$ & 9 & $r, q 4$ & أهمية إعداد مفتاح تصحيح ثابت لأداة التقويم. & Q27 \\
\hline
\end{tabular}

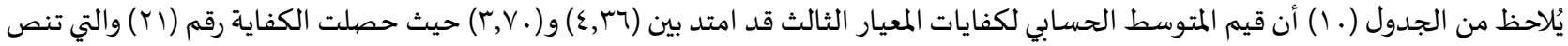

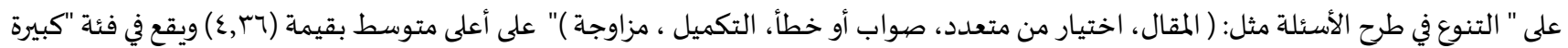

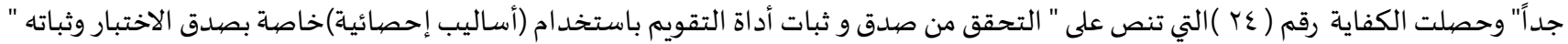

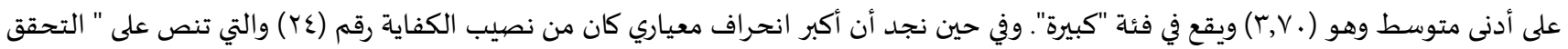


من صددق و ثبات أداة التقويم باستخدام (أساليب إحصائية)خاصة بصدق الاختبار وثباته " بقيمة ( 9 . , ) وهذا دليل على أن اختلاف المعلمات في مدى إدراك الأساليب الإحصائية للتحقق من الصيدق والثبات للاختبار. وفي حين كان أقل تشتت من نصيب الكفاية رقم (YT) والتي تنص على " التنوع في

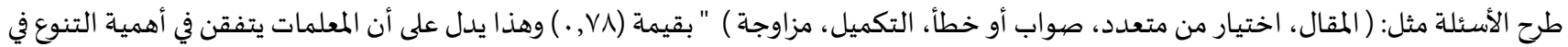

جدول (11): المتوسط الحسابي والانحراف المعياري لإجابات أفراد العينة حسب المعيار الرابع : كفاية تفسيرنتائج عملية القياس و التقويم

\begin{tabular}{|c|c|c|c|c|c|}
\hline \multicolumn{6}{|c|}{ المعيار الرابع: كفاية تفسيرنتائج عملية القياس والتقويم } \\
\hline درجة التوافر & الانحراف المعياري & الترتيب & المتوسط الحسابي & 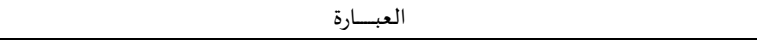 & الرقم \\
\hline 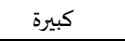 &., 94 & 1 & $\varepsilon, .7$ & الدقة في تحليل، واستخلاص نتائج تقويم أداء الطلبة. & Q28 \\
\hline كبيرة &., 9. & r & $\varepsilon, .0$ & الموضوعية في تصحيح، وتفسير نتائج أداة القياس. & Q29 \\
\hline كبيرة &., 90 & $\varepsilon$ & $r, q \varepsilon$ & تحليل نتائج الاختبار للاستفادة منها في تصحيح مسار تدريس المقرر. & Q30 \\
\hline كبيرة & $1, . \varepsilon$ & $r$ & $r, q \mathrm{~V}$ & تفسير نتائج القياس التي تم التوصل إلهها، طبقًا لمعايير و محكات محددة. & Q31 \\
\hline 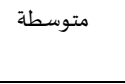 & 1,10 & 1 & $r, r q$ & الغرض . حيم معامل صعوبة فقرات أداة القياس باستخدام (أساليب إحصائية)خاصة لهذا & Q32 \\
\hline متوسطة & 1,17 & $v$ & $r, r q$ & حساب قيم معامل تمييز فقرات أداة القياس باستخدام (أساليب إحصائية)خاصة لهذا & Q33 \\
\hline 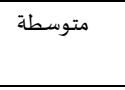 & 1,19 & $\wedge$ & $r, r)$ & الغرض حساب قيم معامل تخمين فقرات أداة القياس باستخدام (أساليب إحصائية) خاصة لهذا & Q34 \\
\hline 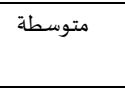 & 1,19 & 7 & $r, r q$ & لهذا الغرض فاعلية المموهات في فقرات الاختيار من متعدد باستخدام (أساليب إحصائية))خاصة & Q35 \\
\hline كبيرة & $1, . r$ & $\circ$ & r,vo & الاستفادة من نتائج تحليل الفقرة في تقييمها إما؛ لتعديلها أو حذفها، أو الإبقاء علهيا. & Q36 \\
\hline كبيرة & $1, .1$ & $r$ & $r, q v$ & تزويد إدارة المدرسة، أولياء الأمور، والطالبات بتقارير دقيقة للنتائج التي تم التوصل إلهها. & Q37 \\
\hline
\end{tabular}

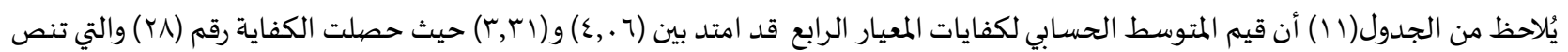
على " الدقة في تحليل، واستخلاص نتائج تقويم أداء الطلبة" على أعلى متوسط بقيمة (ج.,ع) ويقع في فئة "كبيرة" وحصلت الكفايات

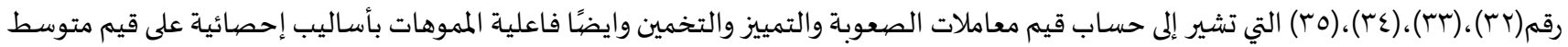

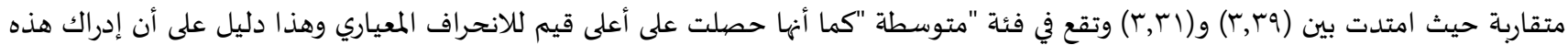

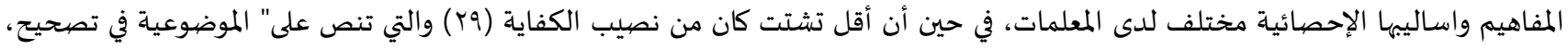
وتفسير نتائج أداة القياس "بقيمةة(. و, .) وهذا دليل على اتفاق المعلمات على أهمية الموضوعية في تفسير النتائج وهذا يتفق مع ما سبق الحصول عليه

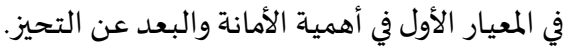

جدول (r ا): المتوسط الحسابي والانحراف المعياري لإجابات أفراد العينة حسب المعيار الخامس: كفاية إصددار الحكم واتخاذ القرارات

\begin{tabular}{|c|c|c|c|c|c|}
\hline \multicolumn{6}{|c|}{ المعيار الخامس:كفاية إصدار الحكم واتخاذ القرارات } \\
\hline درجة التوافر & 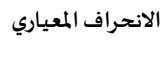 & الترتيب & المتوسط المسبي & 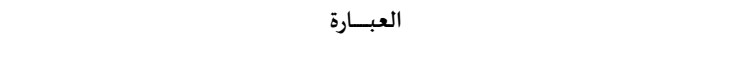 & 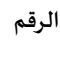 \\
\hline كبيرة &., 10 & 1 & $\varepsilon, 19$ & تحديد مدى تقدم الطالبات، وإتقاهن للمهارات المطلوبة . & Q38 \\
\hline كبيرة & , M & r & $\varepsilon, 10$ & تشخيص صعوبات التعلم لدى الطالبات، والتوصل إلى نقاط القوة، والضعف لديهن. & Q39 \\
\hline كبيرة & $\cdot, \wedge 9$ & $r$ & $\varepsilon, .9$ & تشارهن. مستص حاجات الطالبات، واقتراح الأساليب العلاجية المناسبة للمتأخرات؛ لتصحيح & Q40 \\
\hline كبيرة &., 19 & 。 & $r, q \mathrm{~V}$ & دقة التقديرات، وجودة الأحكام التي تعطى للطالبات أثناء عملية القياس والتقويم. & Q41 \\
\hline كبيرة & $\cdot, \wedge 9$ & 0 & $r, q \vee$ & التحقق من فاعلية وسائل التقويم مناسبة ، أو غير المناسبة. & Q42 \\
\hline كبيرة & .94 & $\circ$ & $r, q v$ & تقدير درجة تحقق الأهداف التعليمية المرسومة . & Q43 \\
\hline كبيرة & .,9r & $\varepsilon$ & $\varepsilon, .1$ & توظيف نتائج التقويم بوضع الخطط العلاجية، والاثرائية المناسبة؛ لتحسين أداء الطلاب & Q44 \\
\hline
\end{tabular}

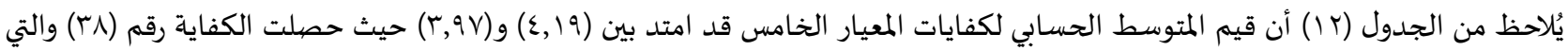

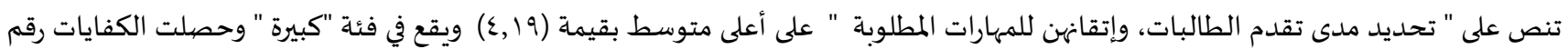

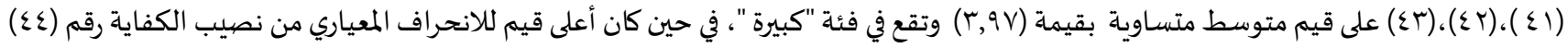

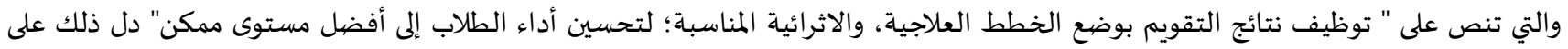
اختلاف المعلمات في إدراك كيفية توظيف ما يتوصلن له من نتائج لتحسين مستوى الطالبات. في حين أن أقل تشتت كان من نصيب الكفاية (^^) والتي 
تنص على" تحديد مدى تقدم الطالبات، وإتقانهن للمهارات المطلوبة " بقيمة (10,.) وهذا دليل على اتفاق المعلمات في إدراك تحديد ما تتوصل إليه

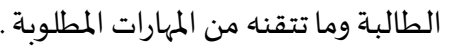
نتائج السؤال الثاني وتفسيرها ومناقشتها: للإجابة عن التساؤل الثاني والذي نصاه " ما درجة ممارسة كفايات القياس والتقويم لدى معلمة التعليم العام بتبوك وفق المعايير العالمية في ضوء

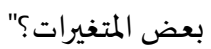
بناء على استجابات عينة الدراسة على بطاقة ملاحظة كفايات القياس والتقويم وفقاً لمقياس ليكرت الخماسي تم الحكم على درجة ممارسة المعلمة لكفايات القياس والتقويم وفق المستويات التالية :

بدرجة كبيرة جداً (ه) : إذا كانت قيمة المتوسط الحسابي من ( • ب, إلى ه)

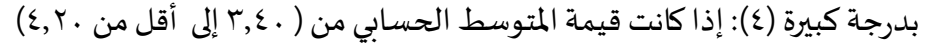

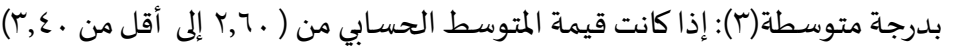

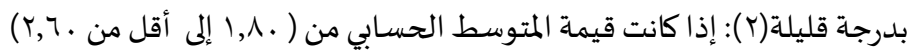

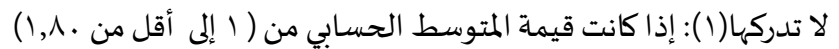
بعد ذلك تم حساب الأوساط الحسابية والانحرافات المعيارية على مستوى بطاقة الملاحظة الكلي والمعايير ، وكذلك على مستوى الكفاية الواحدة في المعيار الواحد : مانم

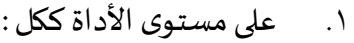
أولاً تم حساب المتوسط الحسابي والانحراف المعياري لإجابات أفراد العينة الخاصة بجميع معايير بطاقة الملاحظة لكفايات القياس والتقويم كما في الجدول . الجماب

جدول (rا)): المتوسط الحسابي والانحراف المعياري لإجابات أفراد العينة الخاصة بجميع معاييربطاقة الملاحظة لكفايات القياس والتقويم

\begin{tabular}{|c|c|c|c|c|c|c|c|}
\hline 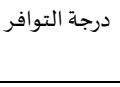 & 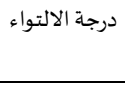 & الانحراف المعياري & الترتيب & الحستابي & 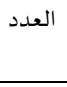 & 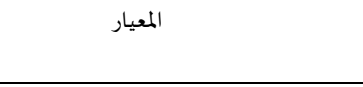 & 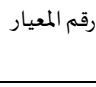 \\
\hline متوسطة &., $0 \mathrm{~V}-$ & $1, . r$ & 1 & $r, r q$ & 0 & الكفايات الأخلاقية للقياس والتقويم & 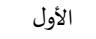 \\
\hline متوسطة &., $99-$ & $\cdot, 9 \mathrm{~V}$ & r & r, ro & 1. & كفاية التخطيط للقياس والتقويم & 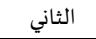 \\
\hline متوسطة & $1,11-$ & $\cdot, \wedge$ & $\varepsilon$ & $r, \cdot r$ & 11 & كفاية تنفيذ عملية القياس و التقويم & 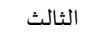 \\
\hline 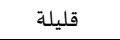 & $1, .7-$ &., 77 & $\circ$ & r, rq & 1. & كفاية تفسير نتائج عملية القياس والتقويم & 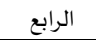 \\
\hline متوسطة &., $\mathrm{OY}-$ & 1,19 & r & $r, r \varepsilon$ & $\checkmark$ & كفاية إصدار الحكم واتخاذ القرارات & 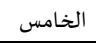 \\
\hline متوسطة &., $9 \vee-$ & $\cdot, \wedge \vee$ & \multicolumn{2}{|c|}{$r, 91$} & $\varepsilon r$ & \multicolumn{2}{|l|}{ 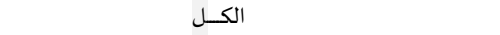 } \\
\hline
\end{tabular}

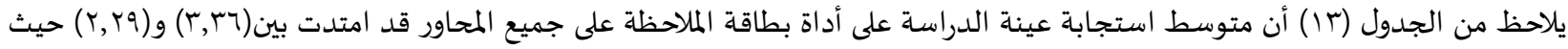

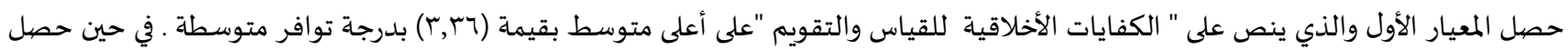

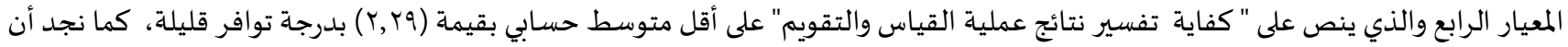

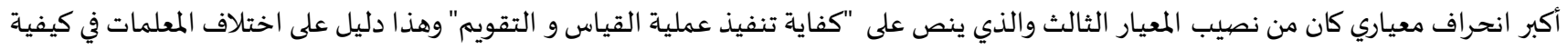

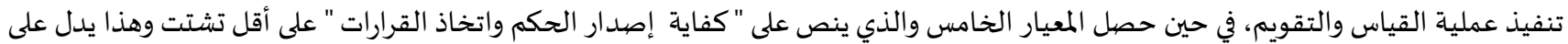

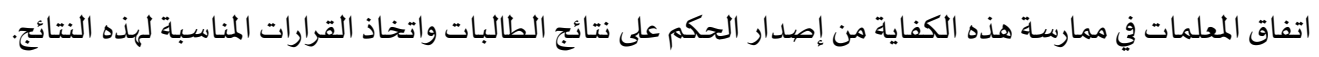

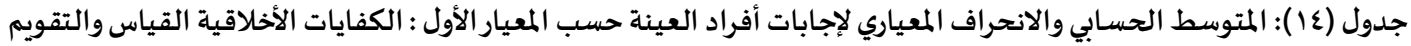

\begin{tabular}{|c|c|c|c|c|c|}
\hline \multicolumn{6}{|c|}{ المعيار الأول :الكفايات الأخلاقية للقياس والتقويم } \\
\hline درجة التوافر & الانحراف المعياري & الترتيب & المسابي & 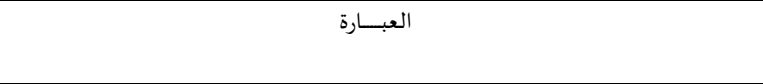 & 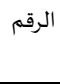 \\
\hline كبيرة & $1, r_{0}$ & r & $r, \sum q$ & تُوظف عملية القياس والتقويم للإبداع في طرائق التدريس. & Q1 \\
\hline متوسطة & 1,11 & $\varepsilon$ & $r, r \Lambda$ & تتعامل المعلمة مع المعلومات والنتائج الفردية للطالبات بسرية تامة. & Q2 \\
\hline كبيرة & $1, .1$ & r & $r, \Sigma 9$ & تتحلي المعلمة بالأمانة عند الاستشهاد بالأدلة، وإصدار الحكم بعيداً عن التحيز. & Q3 \\
\hline كبيره & 1,11 & 1 & $r, 07$ & تقيس السلوك عند الطالبات في مناخ إنساني مُفْعمٌ بالود، والتعاطف بعيد عن الخوف والتوتر. & Q4 \\
\hline كبيرة & $1, .7$ & r & r,or & تحرص على مراعاة الفروق الفردية بين الطالبات أثناء العملية التعليمية & Q5 \\
\hline
\end{tabular}

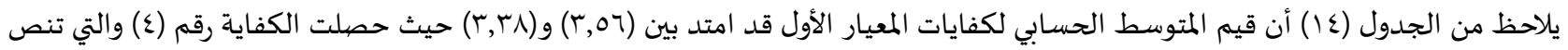

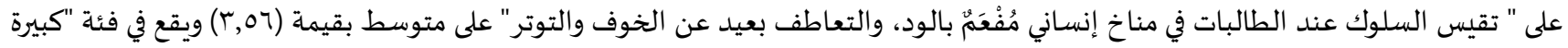

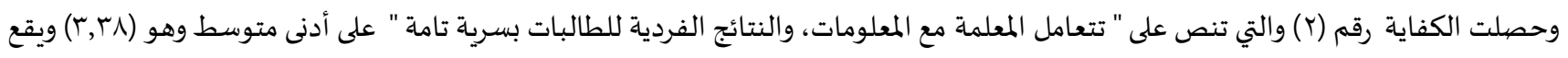


في فئة متوسطة ـ وفي حين نجد أن أكبر انحراف معياري كان من نصيب الكفاية رقم (1) والتي تنص على " تُوظف عملية القياس والتقويم للإبداع في

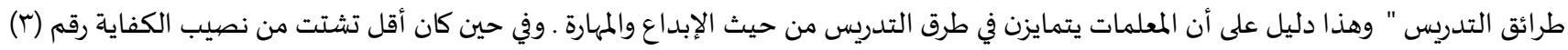

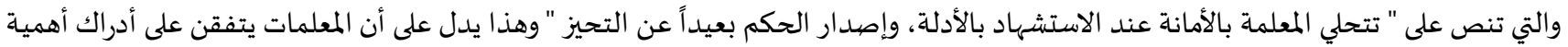

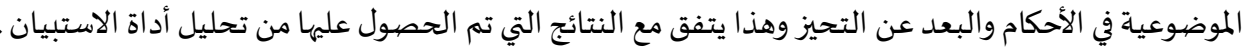

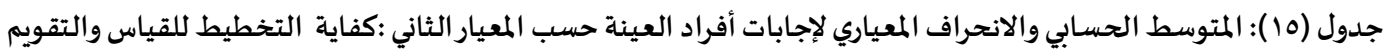

\begin{tabular}{|c|c|c|c|c|c|}
\hline \multicolumn{6}{|c|}{ المعيار الثاني :كفاية التخطيط للقياس والتقويم. } \\
\hline 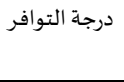 & الانحراف المعياري & الترتيب & المتوسط & 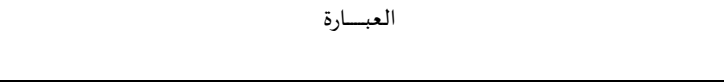 & 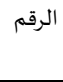 \\
\hline 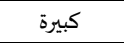 & $\cdot, 10$ & 1 & r,VA & تخطط لأنواع التقويم القبلي، والبنائي، و الختامي . & Q6 \\
\hline 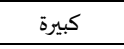 & $1, .1$ & r & $r, 7$. & تربط بين طرائق التدريس المستخدمة، وأساليب القياس. & Q7 \\
\hline 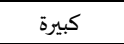 & $1, r \varepsilon$ & 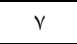 & $r, \varepsilon \varepsilon$ & تُعد خطط واضحة وشاملة العناصر؛ لعملية القياس. & Q8 \\
\hline كبيرة & $1, \cdot r$ & $\varepsilon$ & $r, 0 \Lambda$ & تحدد الغرض الذي من أجله تمت عملية التقويم. & Q9 \\
\hline 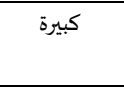 & $1, \cdot r$ & 0 & $r, 01$ & العمليَّة التعليمية. & Q10 \\
\hline كبيرة & $\cdot, \wedge \varepsilon$ & $r$ & $r, 7$. & اتجاهات) . تحرص على شمولية التقويم لمختلف مجالات التعلم من:( معارف، مهارات، قيم، & Q11 \\
\hline متوسطة & $1, .0$ & 9 & r,N & تستخدم جدول المواصفات كدليل في بناء الاختبار. & Q12 \\
\hline متوسطة & $1, r \varepsilon$ & $\wedge$ & $r, q$. & دراسي، و في كل مستوى من بيانات جدول المواصفات في تحديد عدد الأسئلة الخاصية بكل موضوع & Q13 \\
\hline كبيرة & $\cdot, 94$ & r & $r, \mathrm{r}\rceil$ & 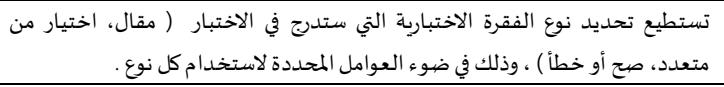 & Q14 \\
\hline 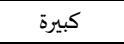 &., $9 \mathrm{~V}$ & 7 & $r, \varepsilon V$ & تستطيع تحديد مستوى الصعوبة المقبولة للفقرات عند بناء الاختبار & Q15 \\
\hline
\end{tabular}

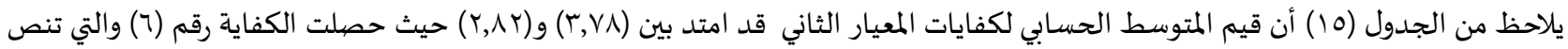

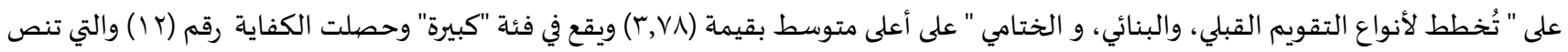

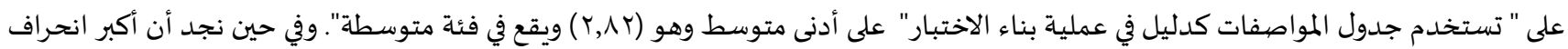

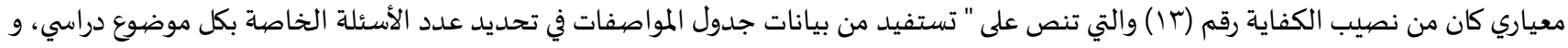

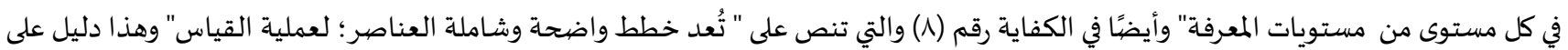

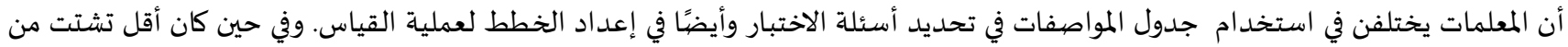

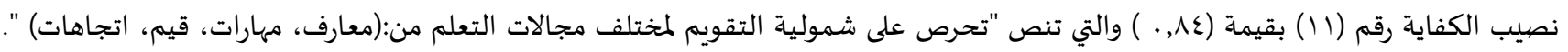

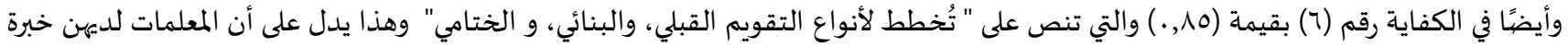

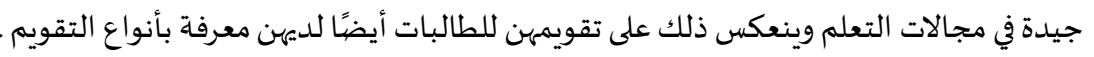

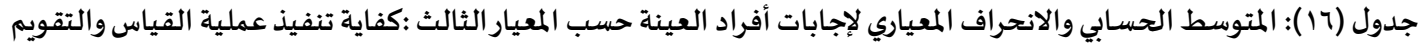

\begin{tabular}{|c|c|c|c|c|c|}
\hline \multicolumn{6}{|c|}{ المعيار الثالث : كفاية تنفيذ عملية القياس و التقويم } \\
\hline 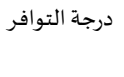 & الانحراف المعياري & الترتيب & المتوسط & 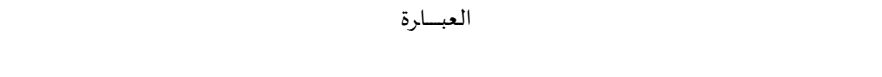 & 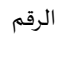 \\
\hline كبيرة &., 94 & $\varepsilon$ & $r, 7$. & تُعد وتُجهز كل ما يلزم لعملية القياس؛ لتسهل طرق تنفيذه. & Q16 \\
\hline كبيرة &., $9 \varepsilon$ & $\varepsilon$ & $r, \eta$. & تقوم باختيار أساليب التقويم المناسبة لظروف الموقف التقويمي، وذلك بحسب العوامل المحددة لذلك. & Q17 \\
\hline كبيرة & $\cdot, 91$ & r & $r, 7 \varepsilon$ & تستخدم أساليب التقويم المتنوعة : كالشفوية، التحريرية، العملية، التقارير البحثية ، السجلات التراكمية؛ & Q18 \\
\hline 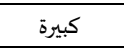 &., 91 & r & $r, 7 \varepsilon$ & تستخدم أساليب التقويم، التي تركز على الأداء مثل: (ملفات أعمال الطالبات، الملاحظة، الأنشطة المنزلية ...) & Q19 \\
\hline كبيرة & $\cdot, \lambda \mathrm{T}$ & 1 & 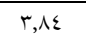 & تحرص على التنوع في طرح الأسئلة مثل: ( المقال، اختيار من متعدد، صواب أو خطأ، اكمال، مزاوجة ) . & Q20 \\
\hline كبيرة & $\cdot, \wedge 9$ & r & r,7r & اكمازن بين مزاوجة ) وعيوب الأشكال المختلفة من فقرات الاختبار ( المقال، اختيار من متعدد، صواب أو خطأ، & Q21 \\
\hline متوسطة & $1, \ldots$ & $\Lambda$ & $r, 7 \mathrm{~V}$ & تشجع الطالبات على التقويم الذاتي. & Q22 \\
\hline لا تلمارس & 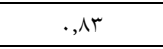 & 9 & 1,11 & تتحقق من صدق و ثبات أداة التقويم. & Q23 \\
\hline متوسطة & 1,11 & 1 & $r, 1 \lambda$ & تكتب إرشادات محددة؛ لتنفيذ أداة التقويم بشكل واضح يسهل اطلاع الطلبة علها. & Q24 \\
\hline كبيرة &., $9 \varepsilon$ & $\circ$ & r,or & تستطيع إخراج أداة التقويم بصورتها النهائية & Q25 \\
\hline متوسطة & 1,49 & v & $r, 9 \Lambda$ & تُعدد مفتاح تصحيح ثابت لأداة التقويم. & Q26 \\
\hline
\end{tabular}




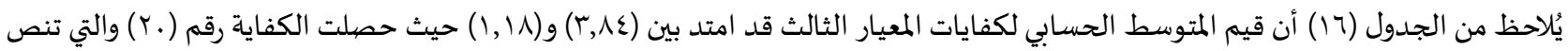

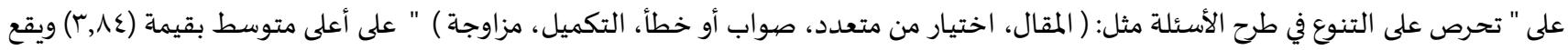

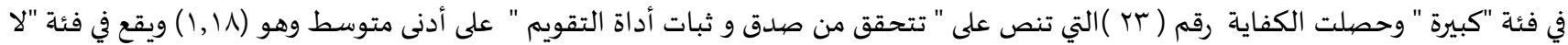

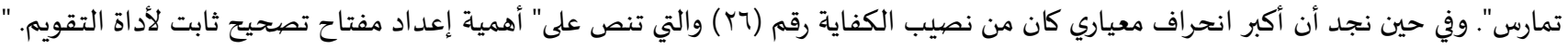

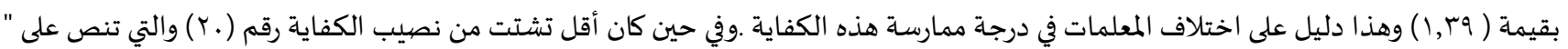

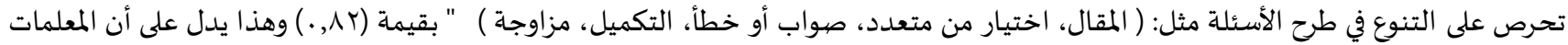

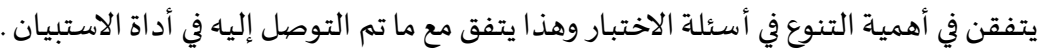

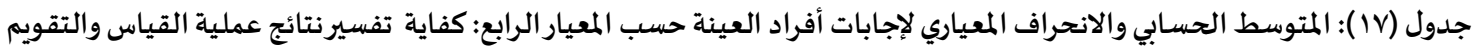

\begin{tabular}{|c|c|c|c|c|c|}
\hline \multicolumn{6}{|c|}{ المعيار الرابع: كفاية تفسيرنتائج عملية القياس والتقويم . } \\
\hline 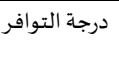 & 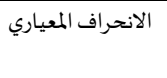 & الترتيب & المتوسط & العبـارة & الرقم \\
\hline كبيرة & $1, .9$ & r & $r, 07$ & تتحرى الدقة في تحليل، واستخلاص نتائج تقويم أداء الطالبات. & Q27 \\
\hline كبيرة &., $9 \varepsilon$ & 1 & $r, 0 \wedge$ & تحرص على الموضوعية في تصحيح، وتفسير نتائج أداة القياس. & Q28 \\
\hline كبيرة & 1,11 & r & $r, \mathrm{r}$, & تقوم بتحليل نتائج الاختبار للاستفادة منها في تصحيح مسار تدربس المقرر. & Q29 \\
\hline متوسطة & $1, .9$ & o & $r, 17$ & تقوم بتفسير نتائج القياس التي تم التوصل الهها، طبقًا لمعايير و محكات محددة. & Q30 \\
\hline ل الاتمارس & $\cdot, \wedge \mathrm{r}$ & 9 & 1,11 & تحسب قيم معامل صعوبة فقرات أداة القياس باستخدام اساليب احصائية خاصة لهذا الغرض & Q31 \\
\hline لا تمارس & . ג r & 9 & 1,11 & تحسب قيم معامل تمييز فقرات أداة القياس باستخدام اساليب احصائية خاصة لهذا الغرض & Q32 \\
\hline لا تمارس & . & $\wedge$ & $1, r$. & تحسب قيم معامل تخمين فقرات أداة القياس باستخدام اساليب احصائية خاصة لهذا الغرض. & Q33 \\
\hline 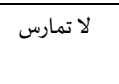 & $1, \cdot r$ & $\mathrm{r}$ & 1,01 & تحسب فاعلية المموهات في فقرات الاختيار من متعدد باستخدام اساليب احصائية خاصة لهذا & Q34 \\
\hline متوسطة & $1, \cdot \mathrm{V}$ & 7 & $r, \wedge 9$ & تستفيد من نتائج تحليل الفقرة في تقييمها إما؛ لتعديلها أو حذفها، أو الإبقاء علهيا. & Q35 \\
\hline متوسطة & $1,1 \mathrm{r}$ & $\varepsilon$ & $r, r q$ & تقوم بتزويد إدارة المدرسة، أولياء الامور، والطالبات بتقارير دقيقة للنتائج التي تم التوصل الهها. & Q36 \\
\hline
\end{tabular}

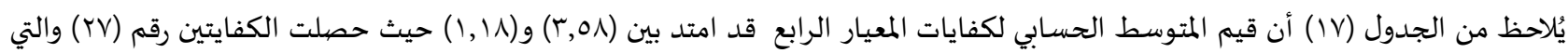

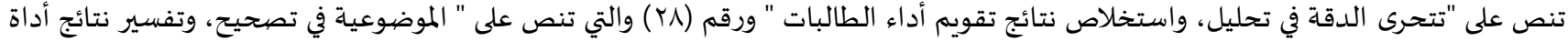

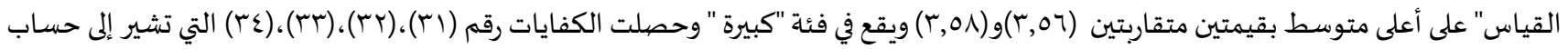

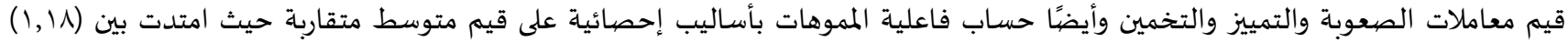

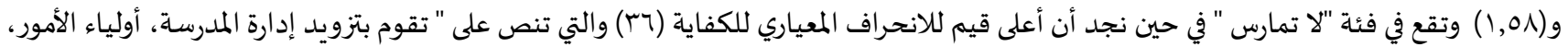

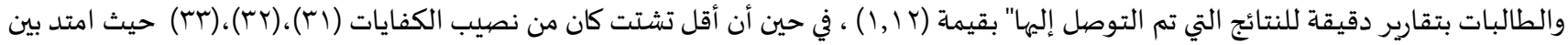

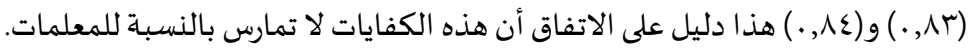

جدول (1) ): المتوسط الحسابي والانحراف المعياري لإجابات أفراد العينة حسب المعيار الخامس: كفاية إصدار الحكم واتخاذ القرارات

\begin{tabular}{|c|c|c|c|c|c|}
\hline \multicolumn{6}{|c|}{ المعيار الخامس: كفاية إصدار الحكم واتخاذ القرارات } \\
\hline درجة التوافر & الانحراف المعياري & الترتيب & 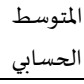 & 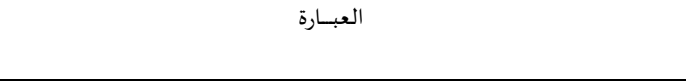 & 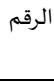 \\
\hline كبيرة & $1,1 \mathrm{r}$ & 1 & $r, \uparrow$. & تُحدد مدى تقدم الطالبات، وإتقاهن للمهارات المطلوبة. . & Q38 \\
\hline كبيرة & 1,19 & $\varepsilon$ & $r, \varepsilon$. & تُشخص صعوبات التعلم لدى الطالبات، للتوصلل إلى نقاط القوة، والضيعف لديهن. & Q39 \\
\hline كبيرة & 1, ro & r & $r, \Sigma q$ & تُشخصن حاجات الطالبات، وتقترح الأساليب العلاجية المناسبة للمتأخرات؛ لتصحيح & Q40 \\
\hline كبيرة & $1,1 \mathrm{~T}$ & $\varepsilon$ & $r, \varepsilon$. & والتقويم. على دقة التقديرات، وجودة الأحكام التي تعطى للطالبات أثناء عملية القياس & Q41 \\
\hline متوسطة & 1,10 & $\circ$ & $r, r \bar{r}$ & تتحقق من فاعلية وسائل التقويم مناسبة ، أو غير المناسبة. & Q42 \\
\hline كبيرة & $1, .9$ & r & $r, \varepsilon r$ & تستطيع تقدير درجة تحقق الأهداف التعليمية المرسومة . & Q43 \\
\hline متوسطة & 1,19 & 7 & $r, r q$ & الطالبات إلى أفضل التقويم بوضتوى ممكن. الخطط العلاجية، والإثرائية المناسبة؛ لتحسين أداء & Q44 \\
\hline
\end{tabular}

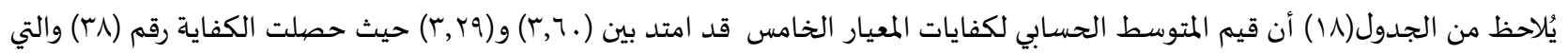

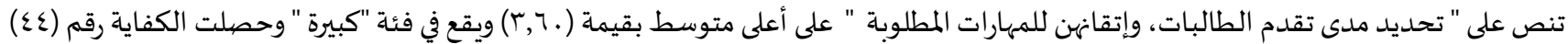

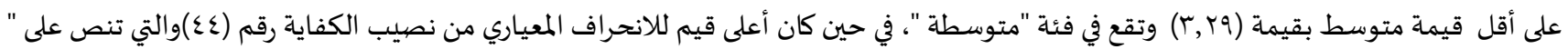


توظف نتائج التقويم بوضع الخطط العلاجية، والإثرائية المناسبة؛ لتحسين أداء الطالبات إلى أفضل مستوى ممكن" دل ذلك على اختلاف المعلمات في مدى ممارسة الخطط العلاجية والإثرائية لتحسين مستوى الطالبات " ، في حين أن أقل تشتت كان من نصيب الكفاية (سع) والتي تنص على" تستطيع

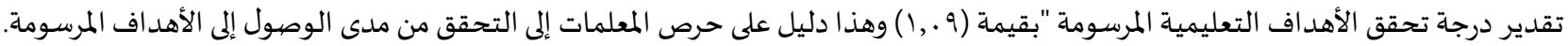
نتائج السؤال الثالث وتفسيرها ومناقشتها: للإجابة عن السؤال الثالث والذي نصها " هل توجد فروق ذات اتفوات دلالة إحصيائية في درجة إدراك المعلمة لكفايات القياس والتقويم تعزى إلى كلاً من

التخصص(علمي ، أدبي) والخبرة ، وعدد الدورات التدريبية في مجال التدريس و التفاعل بينهم؟ قبل الإجابة على هذا السؤال تم التحقق من اتباع واعداع المتغير التابع للتوزيع الطبيعي وذلك عن طريق إجراء اختبار كولمجروف- سميرنوف

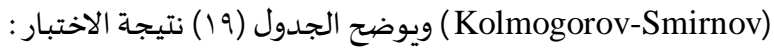

الجدول (19 ) : اختبار التوزيع الطبيعي للمتغير التابع (الإدراك)

\begin{tabular}{|c|c|c|}
\hline \multicolumn{2}{|c|}{ Kolmogorov-Smirnov } & \multirow{2}{*}{ الاختبار } \\
\hline 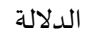 & درجات الحرية & \\
\hline,,$Y \ldots$ & rov & الإدراك \\
\hline
\end{tabular}

يتضيع من قيمة الدلالة أن المتغير التابع يتبع التوزيع الطبيعي ،كما يلاحظ من الجدول (.ب) الذي يبين الوصف الإحصائي للمتغير التابع :

\begin{tabular}{|c|c|c|}
\hline 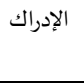 & التابع & الأسلوب الإحصائي \\
\hline$r, . v$ & المتوسط (Mean ) & \\
\hline.,$\Lambda \Lambda$ & الانحراف المعياري(Std. Deviation) & \\
\hline$r, .9$ & الوسيط (Median) & \\
\hline., $.9-$ & الالتواء (Skewness) & \\
\hline . & التفرطح (Kurtosis) & \\
\hline
\end{tabular}

يتبين من الجدول (.ب) أن جميع الإحصاءات الوصفية للمتغير التابع تشير إلى اتباع التوزيع الاعتدالي وهذا ما يؤكد ما توصلنا إليه في الجدول (19).

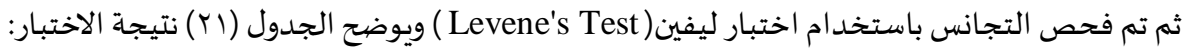
جدول (Yl (Y): اختبار التجانس(Lene's Test ) للمتغير التابع (الإدراك)

\begin{tabular}{|c|c|c|c|}
\hline الدلالة & df2 & df1 & $\mathbf{F}$ \\
\hline r IV & $r \varepsilon 1$ & 10 & $1, r 7$ \\
\hline
\end{tabular}

يتبين من الجدول السابق من قيمة مستوى الدلالة أن التباينات متجانسـة أو متماثلة .

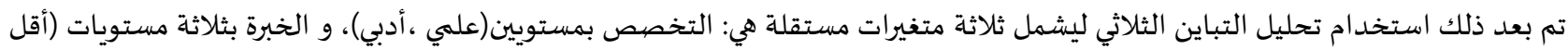

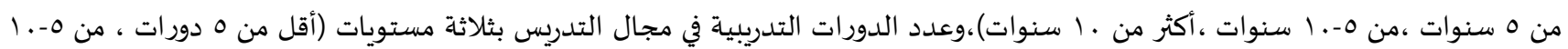

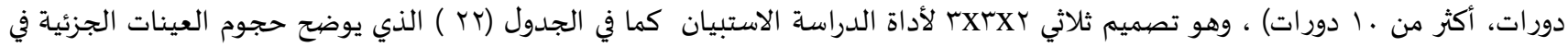

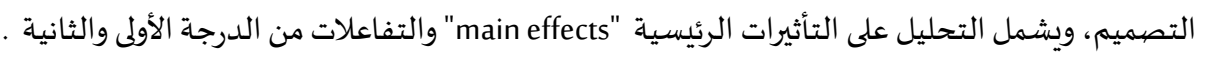
ويبن الجدول (rr) نتائج التحليل لهذا التصيميم لفحص الفروق بين المتوسطات المشار إليها في الجدول ( r ) ) .

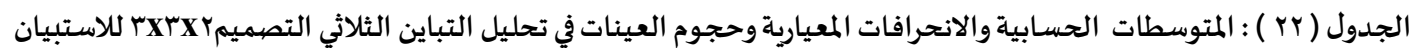

\begin{tabular}{|c|c|c|c|c|c|}
\hline حجم العينة & الانحراف المعياري & المتوسط الحسابي & عدد الدورات التدريبية في مجال التدريس & الخبرة & التخصص \\
\hline 11 & $1, . \varepsilon$ & $r, r q$ & أقل من ه دورات & \multirow[t]{3}{*}{ أقل من ه سنوات } & \multirow{7}{*}{ أدبي } \\
\hline$r$ & . & $\varepsilon, r V$ & من ه -. 1 دورات & & \\
\hline $1 \varepsilon$ & $1, .1$ & $r, \imath$. & المجموع & & \\
\hline rr & .,70 & $r, 94$ & أقل من ه دورات & \multirow[t]{4}{*}{ من 0-. - اسنوات } & \\
\hline ro & . TV & $r, \Lambda)$ & من 0-. ا دورات & & \\
\hline ir &., 79 & r,qr & أكثر من ـ ا دورات & & \\
\hline $\mathrm{v}$. &., 77 & $r, \lambda V$ & المجموع & & \\
\hline
\end{tabular}




\begin{tabular}{|c|c|c|c|c|c|}
\hline r. &., 07 & $\varepsilon, .1$ & أقل من ه دورات & \multirow[t]{4}{*}{ أكثر من · اسنوات } & \\
\hline$\varepsilon 9$ &., $7 \Lambda$ & $\varepsilon, .1$ & من ه -.. دورات & & \\
\hline $7 \varepsilon$ & rT, & $\varepsilon, 11$ & أكثر من · ا دورات & & \\
\hline ITr & . & $\varepsilon, 1$. & المجموع & & \\
\hline or & ., $\mathrm{VO}$ & $r, \lambda V$ & أقل من ه دورات & \multirow[t]{4}{*}{ المجموع } & \\
\hline AV & . & $r, q \varepsilon$ & من 0-. ا دورات & & \\
\hline vV & . & $\varepsilon, 1 \varepsilon$ & أكثر من · 1 دورات & & \\
\hline riv & $\cdot, 7 \Lambda$ & $r, 99$ & المجموع & & \\
\hline$\varepsilon$ &.,$\varepsilon_{0}$ & $\varepsilon, 11$ & أقل من ه دورات & \multirow[t]{3}{*}{ أقل من ه سنوات } & \multirow[t]{15}{*}{ علهي } \\
\hline 0 & . & $r, v \varepsilon$ & من ه-. 1 دورات & & \\
\hline 9 & $\cdot, \varepsilon V$ & $r, 9 \varepsilon$ & المجموع & & \\
\hline 17 & $\cdot, \mathrm{V} 7$ & $r, \lambda T$ & أقل من 0 دورات & \multirow{4}{*}{ من 0-. اسنوات } & \\
\hline rq &., 79 & $r, \lambda V$ & منه-.1 دورات & & \\
\hline 17 &.,$\varepsilon \lambda$ & $\varepsilon, Y \varepsilon$ & أكثر من ـ ا دورات & & \\
\hline 71 & $\cdot$, TV & $r, q \vee$ & المجموع & & \\
\hline 。 & . $\varepsilon r$ & $\varepsilon, \cdot Y$ & أقل من 0 دورات & \multirow{4}{*}{ أكثر من · ا سنوات } & \\
\hline rY & $\cdot, 10$ & $r, \Lambda$ & من ه-.1 دورات & & \\
\hline$r 9$ &., 7 . & $r, \wedge \varepsilon$ & أكثر من · ا دورات & & \\
\hline $\mathrm{v}$. &., 79 & $r, \lambda V$ & المجموع & & \\
\hline ro &., 77 & $r, 9 \varepsilon$ & أقل من ه دورات & \multirow{4}{*}{ المجموع } & \\
\hline 7. & $\cdot, \vee \varepsilon$ & $r, \lambda V$ & من ه-. ا دورات & & \\
\hline 00 &., 09 & $r, 97$ & أكثر من ـ ا دورات & & \\
\hline $1 \varepsilon$. &., TV & $r, q r$ & المجموع & & \\
\hline 10 &., $9 \mathrm{~V}$ & $r, r$. & أقل من ه دورات & \multirow[t]{3}{*}{ أقل من 0 سنوات } & \multirow[t]{15}{*}{ المجموع } \\
\hline$\wedge$ &.,$\leqslant 9$ & $r, 91$ & من 0-. 1 دورات & & \\
\hline$r$ & $\cdot, \wedge \varepsilon$ & $r, v r$ & المجموع & & \\
\hline$r \wedge$ &., 79 & $r, \wedge 9$ & أقل من ه دورات & \multirow{4}{*}{ من ه ـ.. سنوات } & \\
\hline $7 \varepsilon$ &., 71 & $r, \lambda \varepsilon$ & منه-.1 دورات & & \\
\hline rq &., 09 & $\varepsilon, .9$ & أكثر من · ا دورات & & \\
\hline IrI & $\cdot$, TV & $r, 91$ & المجموع & & \\
\hline ro & .,Or & $\varepsilon, \cdot V$ & أقل من ه دورات & \multirow[t]{4}{*}{ أكثر من . ا سنوات } & \\
\hline vo &., 77 & $\cdot r, \varepsilon$ & من ه-. ا دورات & & \\
\hline $1 . r$ &. & $\varepsilon, .0$ & أكثر من · ا دوررات & & \\
\hline $\begin{array}{r}r . r \\
\end{array}$ &., 77 & $\varepsilon, \cdot Y$ & المجموع & & \\
\hline vi &.,$V Y$ & $r, \wedge q$ & أقل من 0 دورات & \multirow[t]{4}{*}{ المجموع } & \\
\hline $1 \varepsilon V$ &., $\mathrm{~V}$. & $r, 91$ & من ه-. ا دورات & & \\
\hline IrT & . & $\varepsilon, .7$ & أكثر من · ا دورات & & \\
\hline rov &., 71 & $r, 97$ & المجموع & & \\
\hline
\end{tabular}

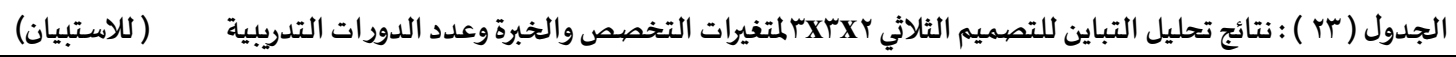

\begin{tabular}{|c|c|c|c|c|c|}
\hline 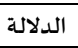 & 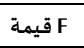 & متوسط المربعات & درجات الحرية & مجموع المربعات & مصبدر التباين \\
\hline., 91 & $\ldots, \ldots$ &.,$\ldots 1$ & 1 &.,$\ldots 1$ & التخصص \\
\hline . $\mathrm{VA}$ & , ro &., 11 & r & , TY & الخبرة \\
\hline . & . $\mathrm{VA}$ & , ro & r & . 79 & عدد الدورات التدريبية \\
\hline., $\mathrm{r \Lambda}$ & $1, \mathrm{rV}$ &., $\mathrm{OV}$ & $r$ & 1,14 & التخصص* الخبرة \\
\hline., 19 & 1,79 &., $\mathrm{VO}$ & $r$ & 1,01 & التخصص * الدورات التدريبية \\
\hline., $0 \varepsilon$ &.,$V Y$ & . & $r$ &., $9 \mathrm{~V}$ & الخبرة*عدد الدورات التدريبية \\
\hline., .7 & $r, 09$ & $1,1 \%$ & $r$ & $r, r)$ & التخصص*|الخبرة*عدد الدورات التدريبية \\
\hline & & . & $r \varepsilon 1$ & $10 r, \varepsilon$. & الخطأ \\
\hline
\end{tabular}




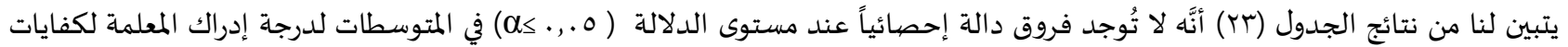

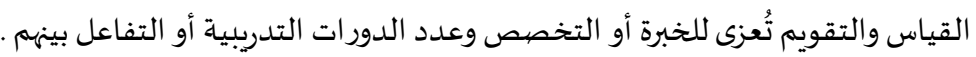
نتائج السؤال الرابع وتفسيرها ومناقشتها: للإجابة عن السؤال الرابع والذي نصاه " هل توجد فروق ذات دلالة إحصائية في درجة ممارسة المعلمة لكفايات القياس والتقويم تعزى لكل من

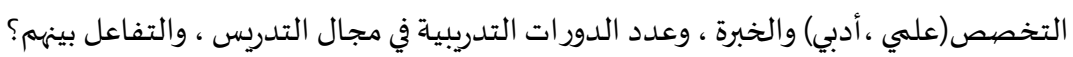
قبل الإجابة على هذا السؤال نحتاج التحقق من اتباع المتغير التابع للتوزيع الطبيعي وذلك عن طريق إجراء اختبار شابيرو-ويلك (Shapiro-Wilk) ويوضح الجدول (乏) نتيجة الاختبار:

الجدول (ع) ) : اختبار التوزيع الطبيعي للمتغير التابع (الممارسة)

\begin{tabular}{|c|c|c|c|}
\hline \multicolumn{2}{|c|}{ Shapiro-Wilk } & \multicolumn{2}{|l|}{ الاختبار } \\
\hline الدلالة & درجات الحرية & & المتغير التابع \\
\hline * & 7. & الممارسة & \\
\hline
\end{tabular}

يتضع من قيمة الدلالة أن توزيع المتغير التابع يتبع التوزيع الطبيعي، كما يلاحظ من الجدول (ro) الذي يبين الوصف الإحصائي للمتغير التابع :

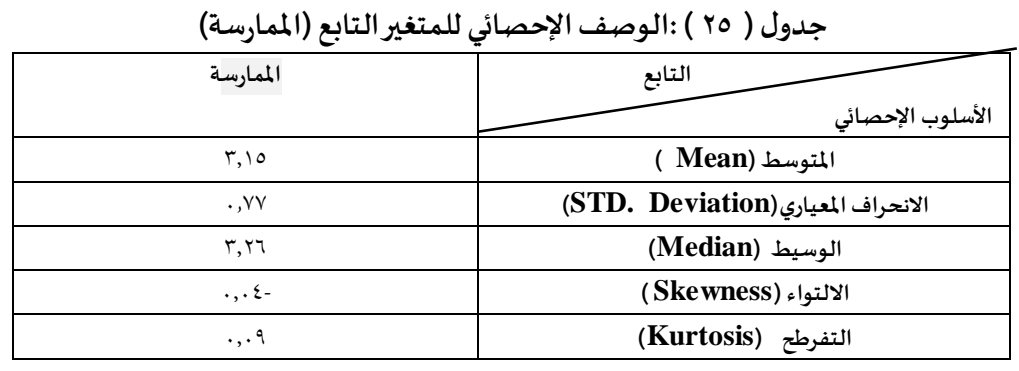

يتبين من الجدول (0) أن جميع الإحصاءات الوصفية للمتغير التابع تشير إلى اتباع التوزيع الاعتدالي وهذا ما يؤكد ما توصلنا إليه في الجدول (ع ب).

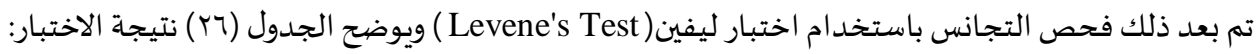
جدول (דr): اختبار التجانس(Levene's Test ) للمتغير التابع (الممارسة)

\begin{tabular}{|c|c|c|c|}
\hline الدلالة & df2 & df1 & $\mathbf{F}$ \\
\hline TIT & $\varepsilon \wedge$ & 11 & $1, \pi r$ \\
\hline
\end{tabular}

يتبين من الجدول (Tr) من قيمة مستوى الدلالة أن التباينات متجانسـة أو متماثلة .

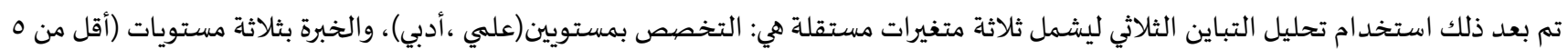

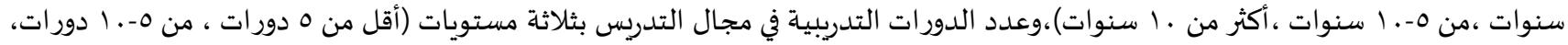

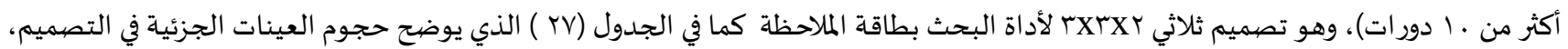
ويشمل التحليل على التأثيرات الرئيسية "main effects" والتفاعلات من الدرجة الأولى والثانية .

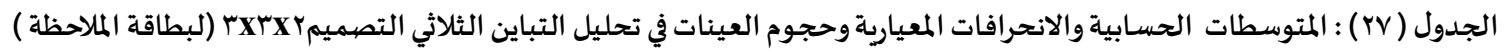

\begin{tabular}{|c|c|c|c|c|c|}
\hline العينة & الانحراف & المستوسط & عدد الدورات التدريبية في مجال & الخبــــرة & التخصص \\
\hline$r$ & $\cdot, \mathrm{AT}$ & $r, 17$ & أقل من ه دورات & \multirow[t]{3}{*}{ أقل من ه سنوات } & \multirow[t]{10}{*}{ أدبي } \\
\hline 0 &., $\mathrm{Y \Lambda}$ & 1,99 & من 0-. 1 دورات & & \\
\hline$\Lambda$ & $\cdot, \leqslant 9$ & $r, .7$ & المجموع & & \\
\hline$\varepsilon$ &.,$Y T$ & r, ro & من 0-. 1 دورات & \multirow[t]{3}{*}{ من 0- . اسنوات } & \\
\hline$r$ & $\cdot, \times 1$ & r,T & أكثر من · ا دورات & & \\
\hline v & $\cdot, \varepsilon \varepsilon$ & $r, Y \varepsilon$ & المجموع & & \\
\hline$\wedge$ & $\cdot, \mathrm{V} 7$ & $r, \wedge \Lambda$ & من 0-. 1 دورات & \multirow[t]{3}{*}{ أكثر من · اسنوات } & \\
\hline 7 &., 19 & r,or & أكثر من · ا دورات & & \\
\hline $1 \varepsilon$ &., 77 & $r, 17$ & المجموع & & \\
\hline$r$ & $\cdot, \lambda r$ & $r, 17$ & أقل من ه دورات & المجموع & \\
\hline
\end{tabular}




\begin{tabular}{|c|c|c|c|c|c|}
\hline IV & $\cdot, \mathrm{VT}$ & $r, r)$ & من 0-. ا دورات & & \\
\hline 9 &.,$\varepsilon Y$ & $r, \varepsilon r$ & أكثر من ـ ا دورات & & \\
\hline rq & , , ,o & $\mathrm{r}, \mathrm{AV}$ & المجموع & & \\
\hline r & .9Y & r,qY & أقل من ه دورات & \multirow[t]{4}{*}{ من ه- . اسنوات } & \multirow[t]{12}{*}{ 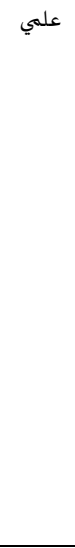 } \\
\hline v & . TV & $r, 91$ & من 0-. 1 دورات & & \\
\hline$\circ$ & .,$\varepsilon \varepsilon$ & $r, \mathrm{~V} 7$ & أكثر من ـ ا دورات & & \\
\hline $1 \varepsilon$ &., 79 & r, ro & المجموع & & \\
\hline$r$ &.,$\leqslant 9$ & $r, r q$ & أقل من 0 دورات & \multirow[t]{4}{*}{ أكثر من · ا سنوات } & \\
\hline 7 & .,or & $r, \varepsilon \vee$ & من 0-. 1 دورات & & \\
\hline 1 &., $\mathrm{V9}$ & $r, 99$ & أكثر من ـ ا دورات & & \\
\hline IV &., $1 \wedge$ & $r, 79$ & المجموع & & \\
\hline$\circ$ & זיד & $r, 19$ & أقل من ه دورات & \multirow[t]{4}{*}{ المجموع } & \\
\hline ir & . & $r, r$, & من ه-. 1 دورات & & \\
\hline 14 &., 77 & $r, q$. & أكثر من ـ ا دورات & & \\
\hline$r$ &., $\mathrm{VI}$ & $r, \leqslant 9$ & المجموع & & \\
\hline$r$ & . AT & $r, 17$ & أقل من ه دورات & \multirow[t]{3}{*}{ أقل من ه سنوات } & \multirow[t]{15}{*}{ مجموع } \\
\hline 0 &., $\mathrm{YA}$ & 1,99 & من 0-. 1 دورات & & \\
\hline$\wedge$ &.,$\leqslant 9$ & $r, .7$ & المجموع & & \\
\hline$r$ &., 94 & $r, q 4$ & أقل من 0 دورات & \multirow[t]{4}{*}{ من 0- ـ. اسنوات } & \\
\hline 11 &., 00 & $r, .1$ & منه ـ.. إدورات & & \\
\hline$\wedge$ &., 01 & $r, 00$ & أكثر من ـ ا دورات & & \\
\hline rI &., 71 & r, ro & المجموع & & \\
\hline$r$ &.,$\leqslant 9$ & $r, r q$ & أقل من ه دورات & \multirow[t]{4}{*}{ اكثر من • اسنوات } & \\
\hline $1 \varepsilon$ & $., \mathrm{n})$ & $r, i r$ & من ه-. 1 دورات & & \\
\hline $1 \varepsilon$ &., $7 \varepsilon$ & $r, v 9$ & أكثر من ـ ا دورات & & \\
\hline$r 1$ & $\cdot, \mathrm{VI}$ & $r, \leqslant 0$ & المجموع & & \\
\hline$\wedge$ & $\cdot, \wedge \varepsilon$ & $r, \Lambda 1$ & أقل من 0 دورات & \multirow[t]{4}{*}{ المجموع } & \\
\hline$r$ r. &., $\mathrm{VT}$ & r, 9 r & من 0-. ا دورات & & \\
\hline rt &., 71 & $r, v$. & أكثر من ـ ا دورات & & \\
\hline 7. &., 19 & $r, 19$ & المجموع & & \\
\hline
\end{tabular}

ويبن الجدول (Y^) نتائج التحليل لهذا التصيميم لفحص الفروق بين المتوسطات المشار إليها في الجدول ( YV ).

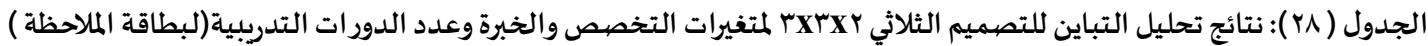

\begin{tabular}{|c|c|c|c|c|c|}
\hline 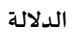 & F قيمة F & متوسط المربعات & درجات الحرية & مجموع المربعات & مصدر التباين \\
\hline$\cdot, \cdot \wedge$ & $r, r$ & $1,1 \mathrm{~V}$ & 1 & $1,1 \mathrm{~V}$ & التخصص \\
\hline$\cdot, \ldots \leqslant *$ & 7,10 & $T, T \varepsilon$ & r & $\varepsilon, \varepsilon 9$ & 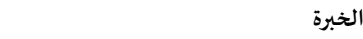 \\
\hline$\cdot, \cdot r^{*}$ & $\varepsilon, 1 r$ & 1,01 & r & $r, .1$ & عدد الدورات التدريبية \\
\hline$\cdot, r$ & $1, .1$ &.,$r q$ & 1 &.,$r q$ & التخصص* الخبرة \\
\hline . & $\cdot, \wedge \mathrm{V}$ &.,$r r$ & 1 &.,$r T$ & التخصص * الدورات التدريبية \\
\hline$\cdot, \wedge \varepsilon$ &., $1 \mathrm{~V}$ &., .7 & r & ., 1r & الخبرة*عدد الدورات التدريبية \\
\hline.,$r t$ & 1,01 &., 01 & 1 &., 01 & التخصص*الخبرة*عدد الدورات التدريبية \\
\hline & &.,$r V$ & $\varepsilon \wedge$ & IV,or & الخطأ \\
\hline
\end{tabular}

يتبين لنا من نتائج الجدول (YN) أنَّهَ لا تُوجد فروق دالة إحصائياً في المتوسطات لدرجة ممارسة المعلمة لكفايات القياس والتقويم تُعزى للتخصص.

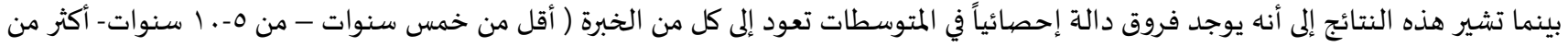

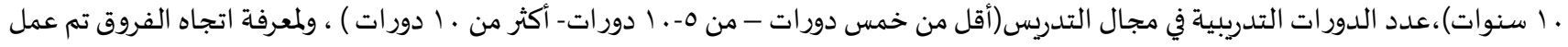

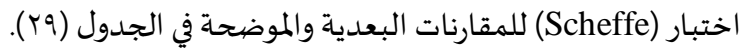


الجدول (Y9): المقارنات البعدية بين مستويات الخبرة

\begin{tabular}{|c|c|c|c|}
\hline 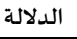 & الخطأ المعياري & متوسط الفروق & الخبرة (r) \\
\hline$\cdot, \ldots$ & $\cdot$, ro & $* 1,19-$ & أقل من ه سـنوات من ه-. اسنوات \\
\hline$\cdot, \cdots$ &., $1 \mathrm{~V}$ & $* 1, r q-$ & أكثر من · ا سـنوات \\
\hline$\cdot, \cdots$ & $\cdot, r \varepsilon$ & $* 1,19$ & من 0-. اسنوات أقل من ه سنوات \\
\hline$\cdot, \leqslant 9$ &., $1 \mathrm{~V}$ & $\cdot, r$ - & أكثر من • ا سنوات \\
\hline$\cdot, \cdots$ &.,$Y \varepsilon$ & $* 1, r 9$ & أكثرمن • اسنوات أقل من • سنوات \\
\hline$\cdot, \leqslant 9$ &., $1 \mathrm{~V}$ & $\cdot, r_{1}$ & من ه-. ا سنوات \\
\hline
\end{tabular}

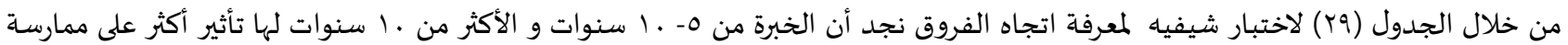

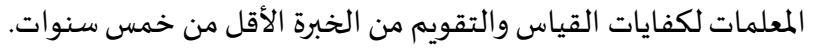

الجدول (·r): المقارنات البعدية بين مستويات عدد الدورات التدريبية في مجال التدريس التبس

\begin{tabular}{|c|c|c|c|}
\hline الدلالة & الخطأ المعياري & متوسط الفروق & الدورات (r) \\
\hline$\cdot, \wedge 9$ & 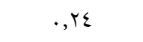 &., $11-$ & أقل من ه دورات من ه-. أدورات \\
\hline.,..$r$ & ., ro & ${ }^{*} \cdot, \wedge \uparrow-$ & أكثر من · ـ دورات \\
\hline$\cdot, \wedge 9$ & $\cdot, Y \varepsilon$ &., 11 & من ه-.. دورات أقل من ه دورات \\
\hline.,$\ldots$ &., $\mathrm{lV}$ & ${ }^{*},, \mathrm{Y} \wedge-$ & أكثر من • ا دورات \\
\hline.,$\ldots r$ & , ro & $* \cdot, \wedge 9$ & أكثرمن · ا دورات أقل من ه دورات \\
\hline.,. &., $\mathrm{lV}$ & $*, \mathrm{r} \wedge$ & من ه-. 1 دورات \\
\hline
\end{tabular}

من خلال الجدول (·r) الذي يوضح اختبار شيفيه لمعرفة اتجاه الفروق نجد أن زيادة عدد الدورات لله أثر على درجة ممارسة المعلمات لكفايات

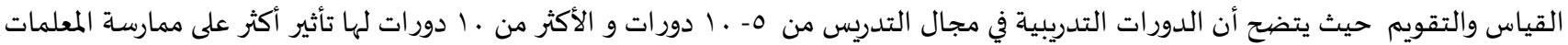

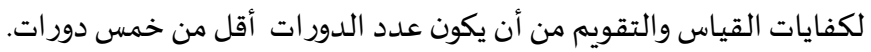
نتائج السؤال الخامس وتفسيرها ومناقشتها:

للإجابة عن السؤال الخامس والذي نصاه " هل يمكن التنبؤ بدرجة ممارسة المعلمة لكفايات القياس والتقويم من خلال درجة الإدراك لها؟

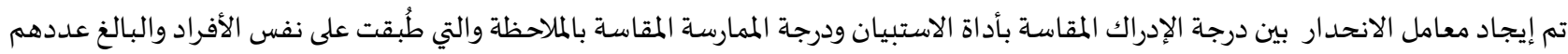

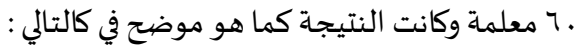

\begin{tabular}{|c|c|c|}
\hline مربع معامل الارتباط & معامل الارتباط & البيان \\
\hline.,$\cdot r$ & . Ir & \\
\hline
\end{tabular}

يتضح من الجدول(آم) أن معامل الارتباط بين إدراك كفايات القياس والتقويم وممارستها في التعليم لدى معلمة التعليم العام قيمته ( ب ا,..) وهو ارتباط ضعيف كما أن التباين المفسر لمتغير إدراك المعلمة كفايات القياس والتقويم يفسر التغيرات في ممارسة كفايات القياس والتقويم بمقدار)

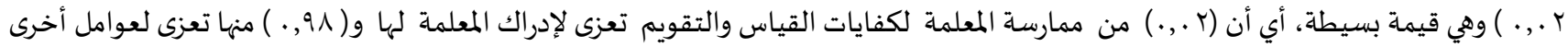

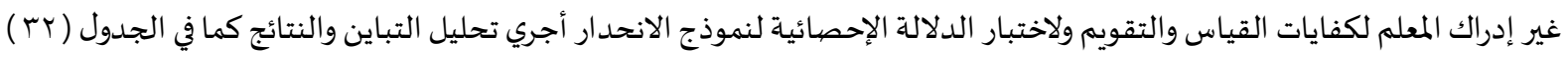
جدول (rr ) : تحليل تباين الانحدار

\begin{tabular}{|c|c|c|c|c|c|}
\hline الدلالة & قيمة F F & متوسط المربعات & درجات الحرية & مجموع المربعات & البيان \\
\hline., ro. $^{\mathrm{b}}$ &., ro. $^{b}$ & . or & 1 & . OTY & الانحدار \\
\hline & &., 09 & 01 & $r \varepsilon, \varepsilon, 7$ & البواقي \\
\hline & & & 09 & $r \varepsilon, q r r$ & المجموع \\
\hline
\end{tabular}

يتضح من الجدول (Yr) أن القدرة التفسيرية لنموذج الانحدار ضعيفة حيث قيمة (F) غير دالة إحصائيا.

جدول(Tr ) : معاملات الانحدار

\begin{tabular}{|c|c|c|c|c|c|}
\hline الدلالة & قيمة T T & بيتا & الخطأ المعياري & B & البيان \\
\hline$\cdot, .+1$ & $r, \varepsilon r$ & & $\cdot, \mathrm{Vr}$ & r,o. & ثابت \\
\hline ., ro &., $9 \varepsilon$ & . IT &., 11 &.,$Y 7$ & الإدراك \\
\hline
\end{tabular}


يتضح من الجدول (rr) أن المتغير المستقل ( إدراك المعلمة لكفايات القياس والتقويم ) لم يكن ذو تأثير دال إحصائيا أو جوهريا في نموذج الانحدار

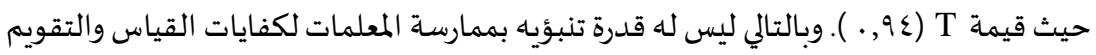

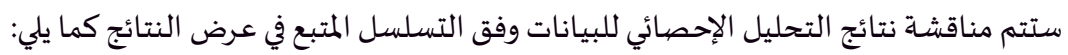

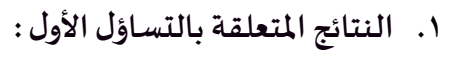

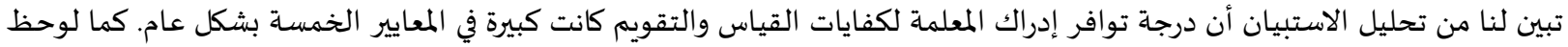

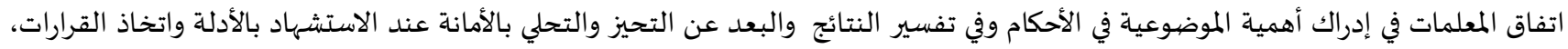

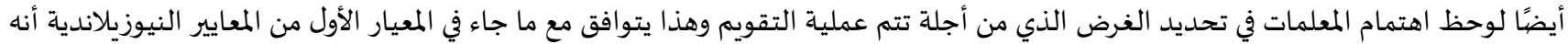

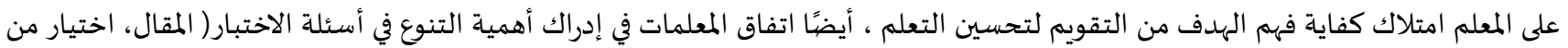

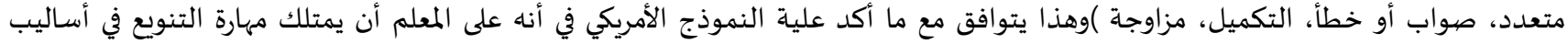

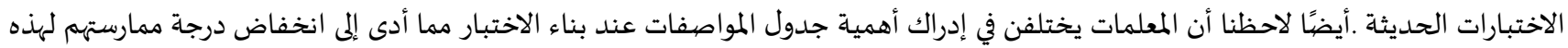

تبين لنا من تحليل بطاقة الملاحظة أن درجة توافر ممارسة المعلمة لكفايات القياس والتقويم كانت متوسطة في كفايات المعايير فيما عدا المعيار

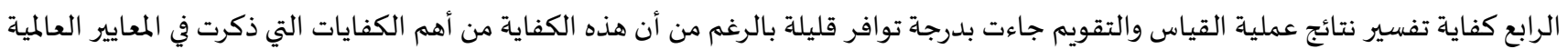

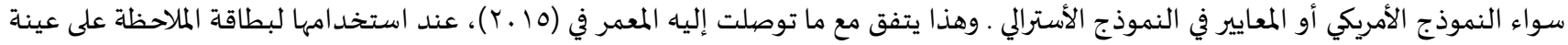

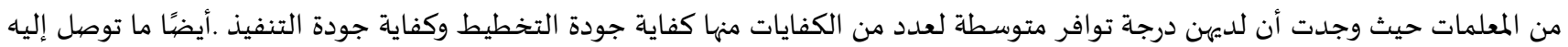

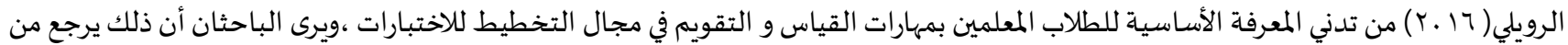

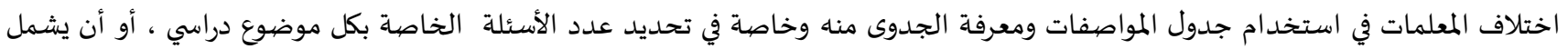

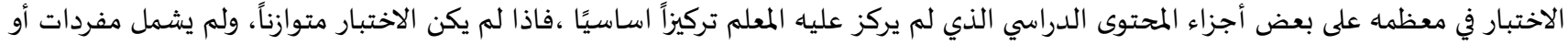

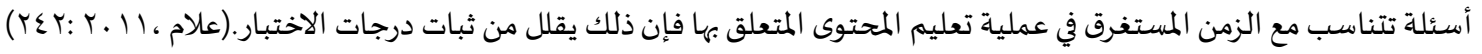
ه وهذا ما نلاحظه من عدم ممارسة أي أساليب للتحقق من صدق وثبات الاختبار، بالنسبة للمعلمة وغير المتخصصبة في القياس أهم نوع من أنواع

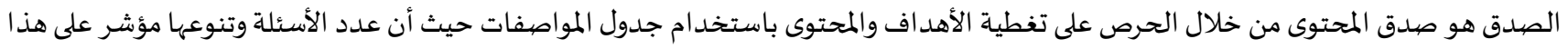

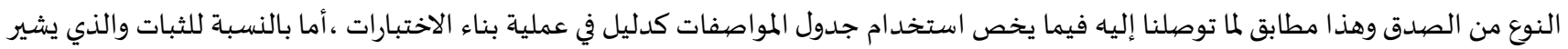

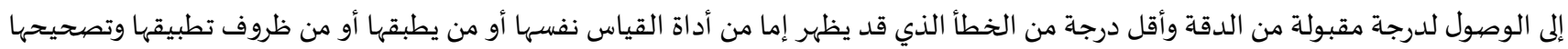

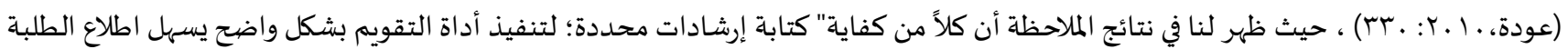

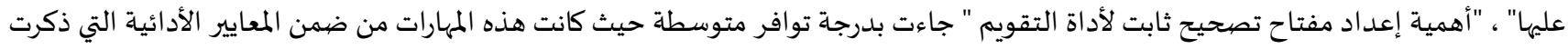

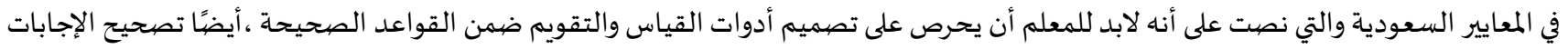

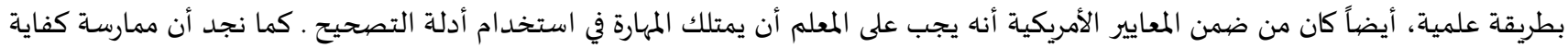

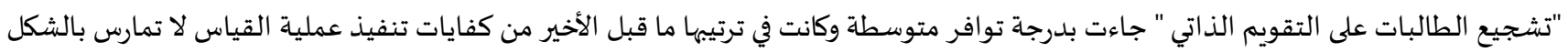

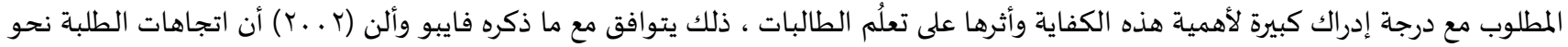

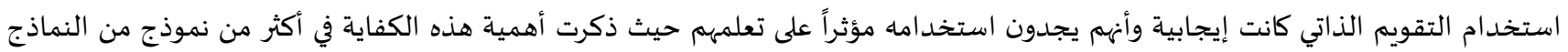

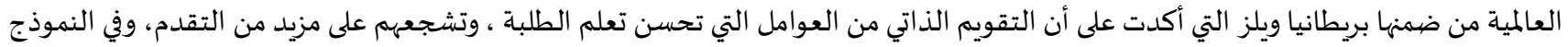

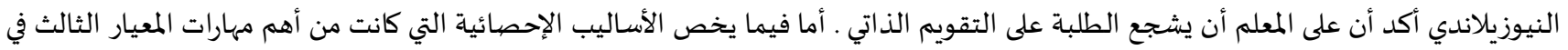

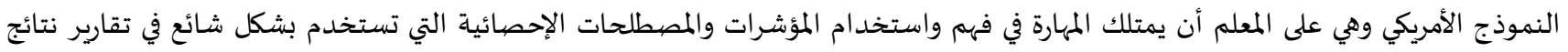

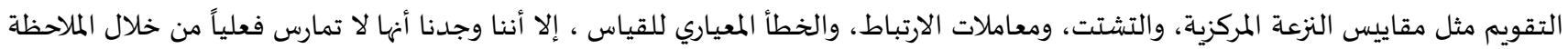

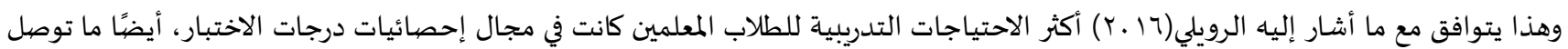

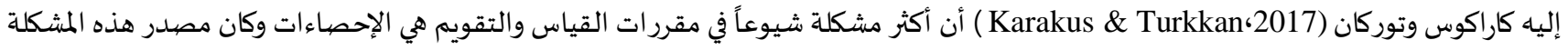

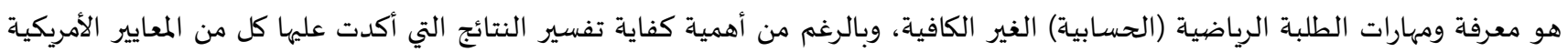

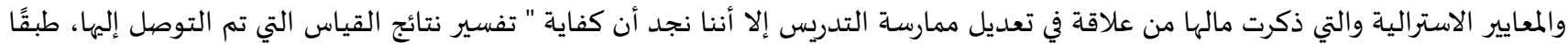


لمعايير و محكات محددة" جاءت بدرجة ممارسة متوسطة وهذا مرتبط فيما توصلنا له في عدم التحقق من ثبات الاختبار حيث أن الدقة في التفسير

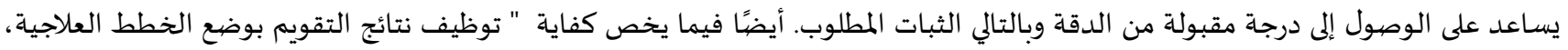

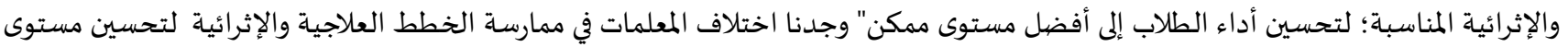
الطالبات " وهذا يتفق مع ما توصل إليه ماتسنوا (Matsenjwa, 2013) حيث خلصت الدراسة إلى أن معلمي المرحلة الابتدائية يقيمون المتعلمين

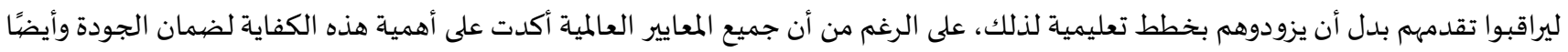

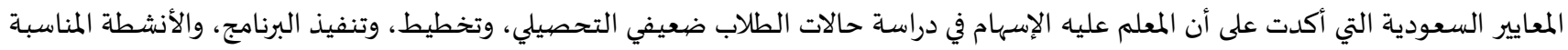

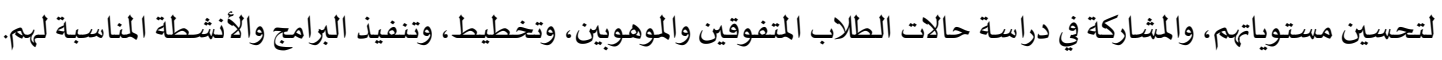

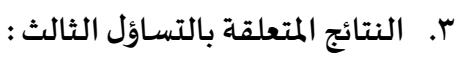

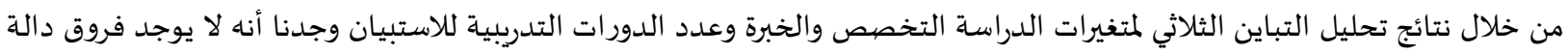

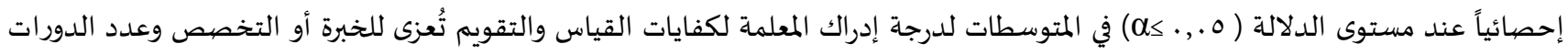

التدريبية .

ع. النتائج المتعلقة بالتساؤل الرابع :

من خلال نتائج تحليل التباين الثلاثي لمتغيرات الدراسة التخصص والخبرة وعدد الدورات التدربية لبطاقة الملاحظة وجدنا أنه لا يوجد فروق

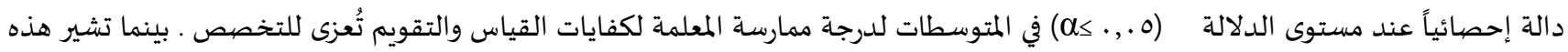

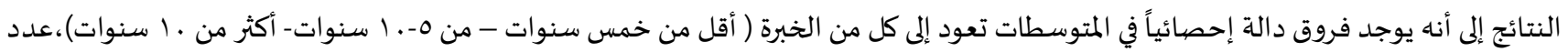

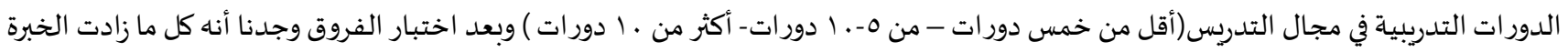

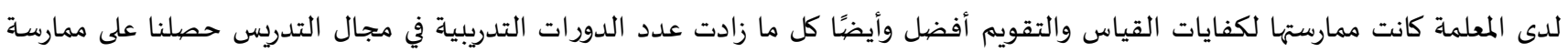

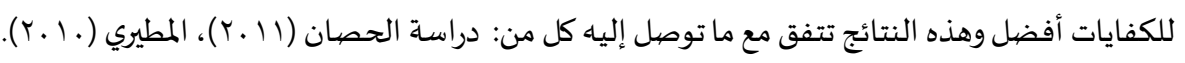
0. النتائج المتعلقة بالتساؤل الخامس : من خلال ما توصلنا إلياه من بحث الارتباط بين درجة إدراك المعلمة لكفايات القياس والتقويم ودرجة ممارستها لها وجدنا أنه ارتباط ضعيف حيث لا

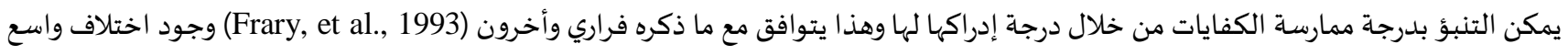

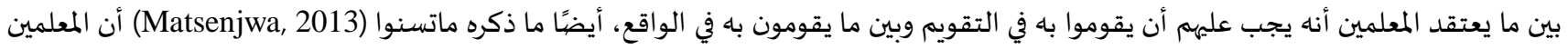

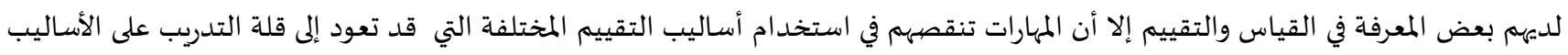

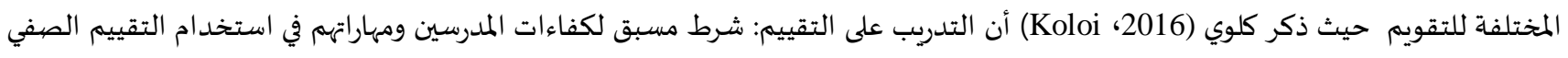

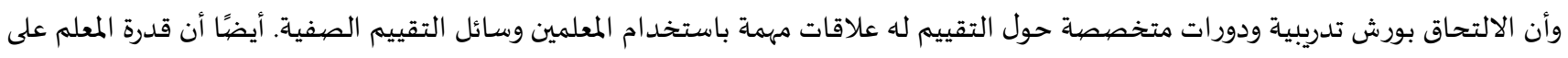

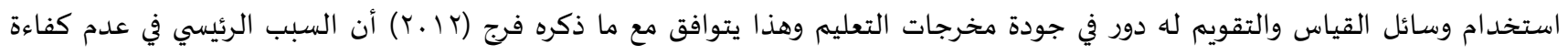

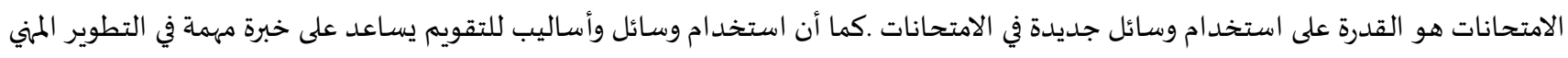

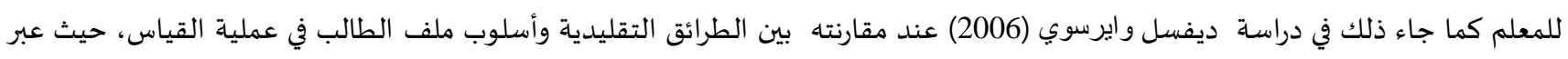
المعلمين أههم يرون أسلوب ملف الطالب أفضل من الأساليب التقليدية في التقويم، وخبرة مهمة في تطورهم المهني. وتتوافق وجهة نظر الباحثان مع الدراسات السابقة أن من أهم أسباب الضيعف بالارتباط بين درجة إدراك المعلمة للكفايات ودرجة ممارستها لها هي

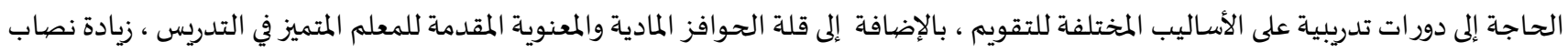
المعلم من الحصص التدريسية ،عدم وجود بيئة مساعدة لتطبيق أساليب مختلفة للتقويم.

توصيات البحثث:

ا. وضع آلية موحدة في جميع الكليات لتدريس مساق التقويم التربوي تتضمن هذه الآلية صياغة إجرائية لأهداف المادة، ومفرداتها، وطرق تدريسها وأساليب التقويم المناسبة لقياس درجة تحقق الأهداف. بحيث تغطي مفردات المادة وأهدافها جميع مهارات القياس وأساليبه

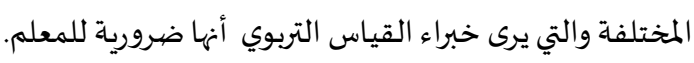

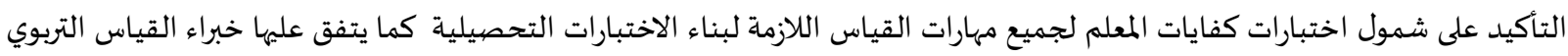
وتوجياء المعلمين الذين تظهر نتائج الاختبار عدم تمكنهم من هذه المهارات إلى ورش تدريات لمعيبة يقوم عليها عدد من المدربين المؤهلين في هذا المجال. 
r. الاستفادة من قائمة المهارات الواردة في هذه الدراسة كإطار مرجعي يساعد المعلم في تقويم كفاءته في مجال القياس والتقويم .

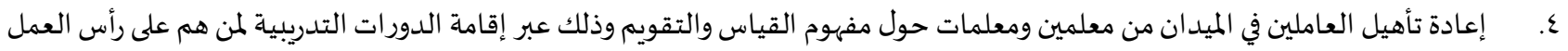

0 0. وضع برنامج تدريبي لتنمية كفايات المعلم بشكل عام وكفايات القياس والتقويم بشكل خاص.

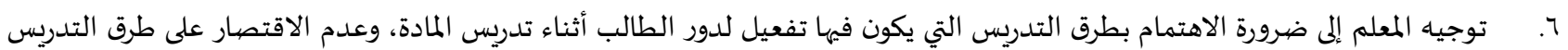

المتمحورة حول المعلم.

V. التركيز على المعلمين ذوي الخبرات العالية من حيث زيادة الحوافز والدعم لأهمية عامل الخبرة التعليمية في تحقيق النجاح في العملية

التعليمية التعلمية.

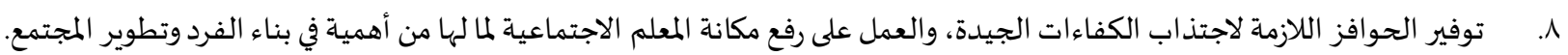
9. تشجيع المعلمين على التخطيط للقياس لما لعنصر التخطيط من أهمية في التحكم في العملية التربوية واختيار أفضل الأساليب والمهارات

للتقويم على أكمل وجه.

• ا. العمل على تنمية مهارات وكفايات المعلمين فيما يتعلق بامتلاك وممارسة مجموعة من الكفايات التدريسية والمتعلقة باستخدام أساليب

التقويم الذاتي للتلاميذ، وتصميم وإنتاج الوسائل التعليمية.

مقترحات:

ا. إعداد برنامج تدريبي بعنوان " القياس والتقويم بين الواقع والمأمول".

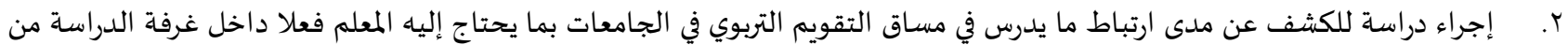
متطلبات أسساسية في القياس والتقويم. r. إجراء دراسة أخرى في نفس المجال لكن من وجهة نظر الطلبة للتعرف على توافر الكفايات لدى المعلم من وجهة نظرهم.

المراجع:

أولاً: المراجع العربية:

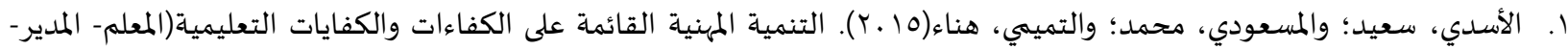

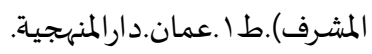

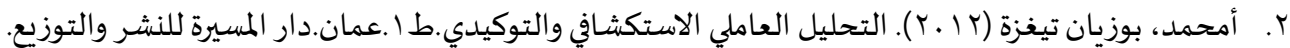

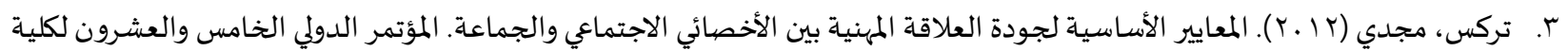

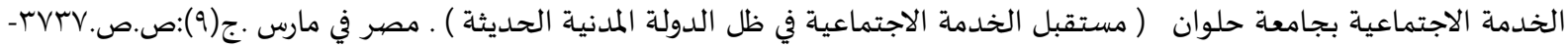

rvar

ع. حسين، أسامة ماهر (1 (1). فعالية برنامج تدريبي مقترح لتنمية الكفاءة المهنية لدى معلمي التعليم الأساسي في مجال القياس والتقويم التربوي في ضوء نتائج اختبارات الترخيص لمزاولة مهنة التعليم والمعايير القومية لجودة المعلم في مصر. مستقبل التربية العربية-مصر.

م) م(1/)

0. الحصان، نجلاء بنت عبد العزيز محمد( (11 ـ ). الكفايات التدريسية اللازمة معلمات رياض الأطفال في مدينة الرياض في ضوء معايير

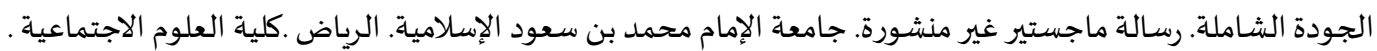

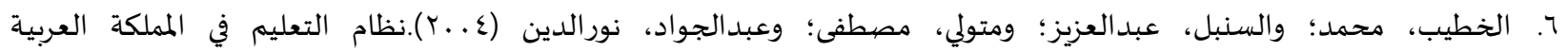

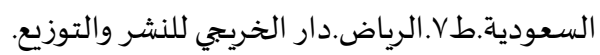

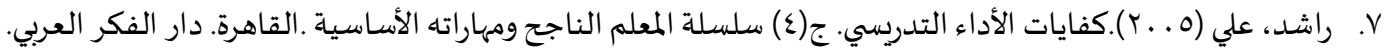

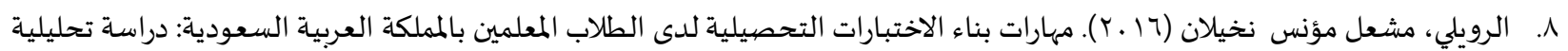

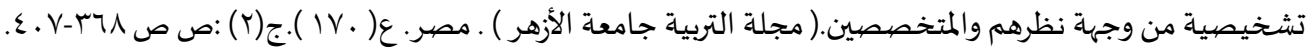

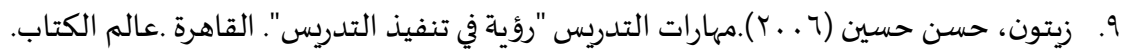

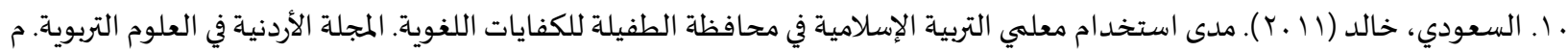

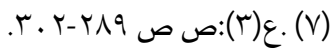




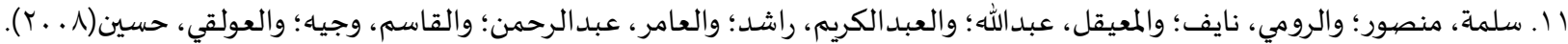

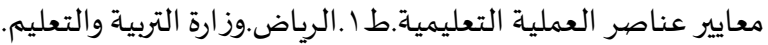

$$
\begin{aligned}
& \text { r ا.. علام، صلاح الدين (1 ا ـ (Y). القياس والتقويم التربوي والنفسي أساسياته وتطبيقاته وتوجيهاته المعاصرة ـ القاهرة ـ دار الفكر العربي. }
\end{aligned}
$$

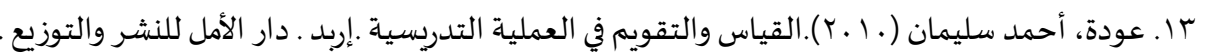

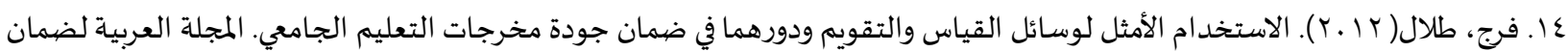

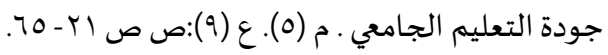

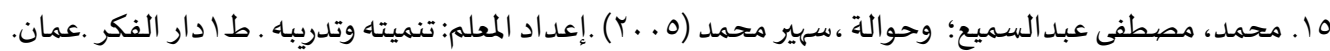

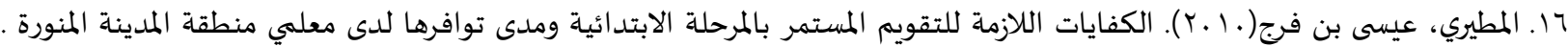

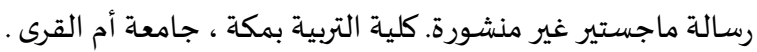

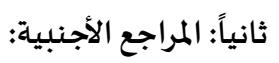

[1] American Federation of Teachers, National Council on Measurement in Education and National Education Association. (1990). Standards for Teacher Competence in Educational Assessment of Students. Retrieved from: http://buros.org/standards-teacher-competence-educationalassessmentstudents.

[2] H. Devecl, A. Ersoy, \& A Ersoy, (2006). The Views of Prospective Elementary School Teachers on the Use of Portfolios Assessment in Teacher Education. Educational Sciences. Theory \& Practice. 6 (1). 193-199.

[3] R.F Flippo, \& D.D Allen, (2002). Alternative Assessment in the preparation of Literacy Education. Responses from Students. Reaing Psychology. 23, 15-26

[4] M. Karakus, \& B. T. Turkkan, (2017). Investigating the Needs for Measurement and Evaluation Course: A Case Study on English Language Teaching Program. Journal of Education and Training Studies.Vol .5.No.4.pp227-239.

[5] Koloi-Keaikitse, S. (2016). Assessment training: a precondition for teachers' competencies and use of classroom assessment practices. International Journal of Training and Development Vol .20.No.2.pp107-123.

[6] L.R. Matsenjwa, (2013). Primary school Eachers knowledge and skills of measurement and assessment:A case of Swaziland. Problems of Education in the 21st Century. Vol.55.PP74-87.

[7] S. M. Özdemir, (2013). Elementary Teacher Competencies and Inservice Training Needs in Alternative measurement and Assessment tools. Journal of Turkish Educational Sciences, 3(4), 813-816.

[8] Southeast Ministers of Education Organization. (2010). Teaching Competency Standards in Southeast Asian Countries: Eleven Country Audit. Retrieved from: //http:// www.seameoinnotech.org.

[9] The Australian Institute for Teaching and School Leadership. (2011). Australian Professional Standards for Teachers: February 2011 Formerly the National Professional Standards for Teachers. Retrieved from //http:// https://www.aitsl.edu.au/teach/standards

[10] The Quality Assurance Agency for Higher Education. (2006). Code of Practice for the Assurance of Academic Quality and Standards in Higher Education. Retrieved from //http://www.qaa.ac.uk/en. 


\title{
The Competencies of Measurement and Evaluation in The General Education in Tabuk Sector according to the International Standards and in the light of Some Variables
}

\author{
Ahmad Salem Al-masoudi \\ Associate Professor of Learning and Individual Differences- Tabuk University- KSA Arabia \\ Unm3030@yahoo.com
}

Hind Abdullah Aljasser

Master of Measurement Calendar- The Ministry of Education

h-m-r44@hotmail.com

\begin{abstract}
:
This study aims at determining the competencies of evaluation and measurement in for the female teachers in the general education sector according to the international standards and in the light of some variables. Two research tools were designed. A questionnaire to study the perception of the female teachers to the competencies of evaluation and measurement and the research sample of this tool included (357) female teacher in the city of Tabuk. The second was an evaluation card to study the practice of the competencies of evaluation and measurement. The research sample included here (60) female teacher. (SPSS) and (AMOS) were used to analyze the data. The results included a high level of the perception for each standard of the evaluation standards. The results also included no statistical differences in the perception of the competencies in the light of the experience, major and training sessions. There are also no statistical differences in the level of practicing the competencies in the light of the major, but there are differences in the light of the experience and training sessions. The recommendations included the benefit of using the list of skills in this study as a reference to help female teachers in self-evaluation.
\end{abstract}

Keywords: competencies, evaluation, measurements, international standards. 